\title{
CONCEPT MASTER
}

A COMPUTER CODE FOR CONCEPTUAL

COST ESTIMATES OF STEAM-ELECTRIC

POWER PLANTS

\section{STATUS REPORT}

\section{APRIL 1971}

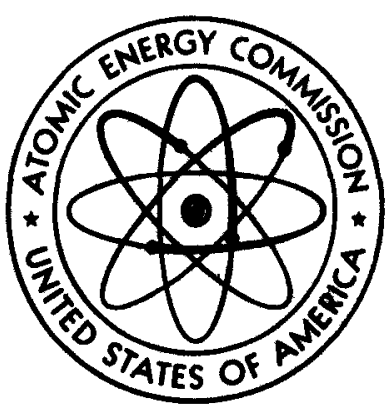

DIVISION OF REACTOR DEVELOPMENT AND TECHNOLOGY

U.S. ATOMIC ENERGY COMMISSION 


\section{DISCLAIMER}

This report was prepared as an account of work sponsored by an agency of the United States Government. Neither the United States Government nor any agency Thereof, nor any of their employees, makes any warranty, express or implied, or assumes any legal liability or responsibility for the accuracy, completeness, or usefulness of any information, apparatus, product, or process disclosed, or represents that its use would not infringe privately owned rights. Reference herein to any specific commercial product, process, or service by trade name, trademark, manufacturer, or otherwise does not necessarily constitute or imply its endorsement, recommendation, or favoring by the United States Government or any agency thereof. The views and opinions of authors expressed herein do not necessarily state or reflect those of the United States Government or any agency thereof. 


\section{DISCLAIMER}

Portions of this document may be illegible in electronic image products. Images are produced from the best available original document. 


\section{CONCEPT: A COMPUTER CODE FOR CONCEPTUAL COST ESTIMATES \\ OF STEAM-ELECTRIC POWER PIANTS - STATUS REPORT}

\section{APRIL 1971}

This report was prepared as an account of work sponsored by the United States Government. Neither the United States nor the United States Atomic Energy Commission, nor any of their employees, nor any of their contractors, subcontractors, or their employees. makes any warranty, express or implied, or assumes any legal liability or responsibility for the accuracy, completeness or usefulness of any information, apparatus, product or process disclosed, or represents that its use would not infringe privately owned rights.

Based on Information Prepared by Oak Ridge National Laboratory

For the Atomic Energy Commission

Under AEC Contract No. W-7405-eng-26 
•

• 


\section{ABSTRACT}

A computer code, CONCEPT, is being developed to provide conceptual capital cost estimates for single-unit nuclear and fossil-fueled power plants. Cost estimates can be made with this code as a function of plant type and size, location, and date of operation. Output from the code includes a detailed breakdown of the estimate into direct and indirect costs according to the USAEC accounting system described in document NUS -531 .

The cost model currently provided by the code is only for PWR plants, but work is in progress to provide cost models for other types of power plant, including BWR, IMHBR, coal-fired and oil-fired plants.

Keywords: capital costs, power costs, power plant economics. 
•

• 
The viability of the nuclear power industry largely depends on competitive capital cost for the nuclear power plants since most of the energy cost is due to fixed charges on the capital investment (the fuel cycle contributes about one-fourth of the total power cost). In the marketplace the cost of a nuclear power plant must be weighed against the capital cost of alternative power plant types that burn fossil fuels. The capital cost of all types of plants will vary with location and will differ with utility practice. The competitiveness of alternate power plant types also will change depending on local labor availability and on economic ground rules and their interpretations.

Estimates of future capital costs of power plants are often determined by applying arbitrarily selected compound interest factors to major elements of the cost structure or occasionally to the total cost. An alternate approach not often resorted to because of expense is the escalation of the components of a detailed estimate. The need to produce a more rational and rapid method of estimating escalation by application of variable factors, not only to each account and subaccount, but also to further divisions of each account into categories such as equipment, site labor and materials, was the reason for performing this study.

This report describes a computer program, CONCEPT, which calculates plant capital costs for a specified set of ground rules. The program was developed as part of the program analysis activities of the AEC Division of Reactor Development and Technology and the work was performed by the Capital Cost Evaluation Group at the Oak Ridge National Laboratory. CONCEPT was designed primarily for use in examining average trends in costs, identifying important elements in the cost structure, determining sensitivity to technical and economic factors, and providing reasonable long range projections of costs. Cost estimates produced by CONCEPT are not intended as substitutes for detailed cost estimates for specific projects. 
In using CONCEPT it is necessary to assemble costs for reference plants of the alternate types of plants under consideration. Work is underway to assemble the cost data for PWR, BWR, LMFBR, HTGR, oil-fired and coal-fired plants. These cost data ultimately will include costs for anticipated environmental control measures for both the nuclear and fossil plants.

Utilities now have an unprecedented number of power plant types available to meet growing energy requirements. The selection of a plant which will provide the most economic power, while complying with environmental requirements, will be influenced by many factors. The computer program described in this report is designed to provide a rapid means of comparing future capital costs of different plants under various sets of economic and technical ground rules.

Milton Shaw, Director Division of Reactor Development and Technology 


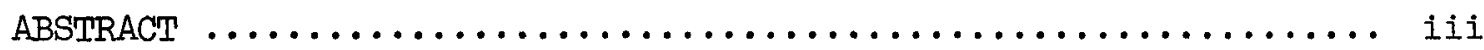

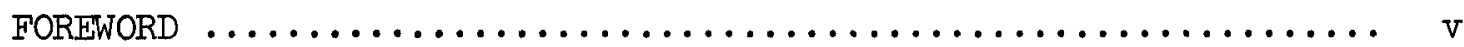

LIST OF FIGURES $\ldots \ldots \ldots \ldots \ldots \ldots \ldots \ldots \ldots \ldots \ldots \ldots \ldots \ldots \ldots \ldots \ldots \ldots$

INTRODUCTION $\ldots \ldots \ldots \ldots \ldots \ldots \ldots \ldots \ldots \ldots \ldots \ldots \ldots \ldots \ldots \ldots \ldots$

DESCRIPTION OF THE COMPUTER CODE $\ldots \ldots \ldots \ldots \ldots \ldots \ldots \ldots \ldots \ldots \ldots \ldots$

COST MODEL FOR PWR PLANTS $\ldots \ldots \ldots \ldots \ldots \ldots \ldots \ldots \ldots \ldots \ldots \ldots \ldots$

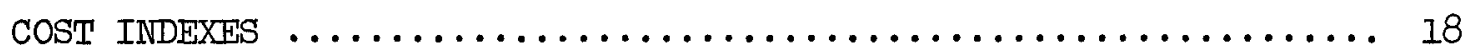

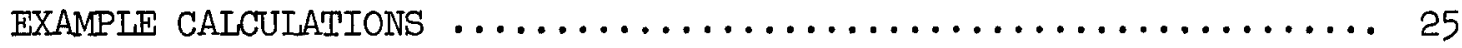

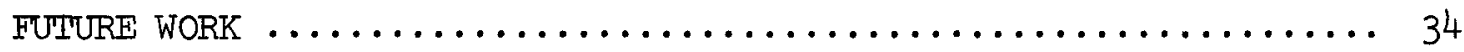

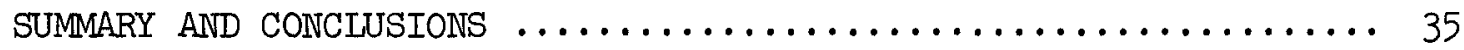

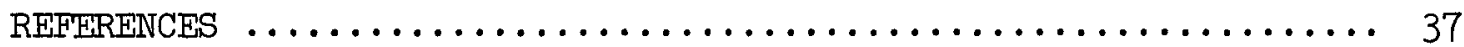


1 Method Used to Adjust Base Costs in CONCEPT .......... 4

2 CONCEPT - General Flow of Calculations ............ 5

3 Typical Computer Output Summary .................. 9

4 Typical Computer Output - Breakdown of Two-Digit

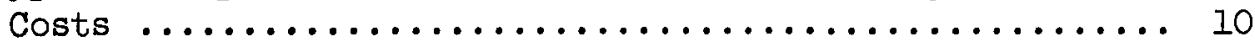

5 Typical Computer Output - Three- and Four-Digit

Levels $\ldots \ldots \ldots \ldots \ldots \ldots \ldots \ldots \ldots \ldots \ldots \ldots \ldots \ldots \ldots \ldots \ldots$

6 Typical Computer Output - Indirect Costs ............ 12

7 Typical Cumulative Cash Flow Curve ............... 13

8 Physical Plant Direct Costs for PWR Plants

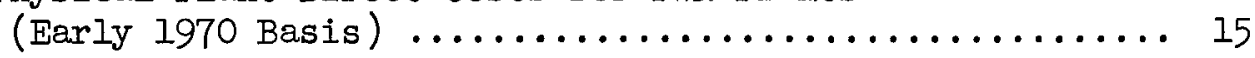

9 PWR Cost Model Constants for Dividing Two-Digit

Direct Costs into Factory Material, Factory

Labor, Site Material, and Site Labor ............ 16

10 Two-Digit Account Cash Flow Curves ............... 17

11 Typical PWR Cost Model Constants for Allocating

Account 22 Cost Components to the Three-Digit

Accounts ............................... 19

12 Cost Index Array for AEC Reference site ............. 20

13 Twenty U.S. Cities for Which Data Are Stored

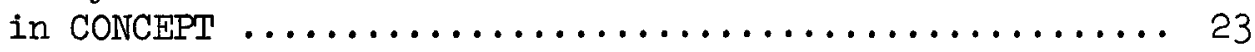

14 Projections of Skilled Labor Rates for Middletown

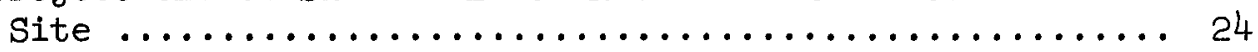

15 Effects of Sustained Overtime on Productivity of

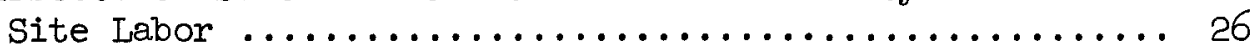

16 Linear Extrapolation of Capital Costs of PWR Plants

in Five Cities as a Function of Year of Start of

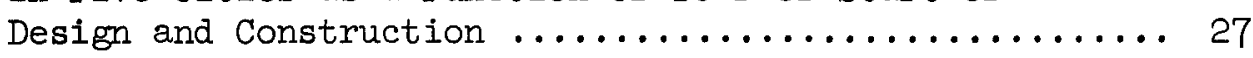

17 Exponential Extrapolation of Capital Costs of PWR

Plants in Five Cities as a Function of Year of

Start of Design and Construction ............... 28

18 Capital Cost as a Function of Unit Size ............ 30

19 Capital Cost as a Function of Design and

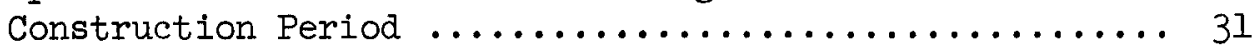

20 Capital Cost as a Function of Workweek ............ 32

21 Capital Cost as a Function of Interest Rate ......... 33 
The total cost for power generation depends greatly on the capital cost of the power plant. This is especially true for nuclear plants, since $75 \%$ or more of the energy cost is due to fixed charges on capital investment. Thus accurate estimates of capital costs are essential in comparing the economic merits of different power plants.

For application in system expansion studies, these capital cost estimates should be based on the specific location and operating date being considered. This requires an understanding of trends in cost components, such as labor rates, labor productivity, and material and equipment prices, as a function of location and time.

A computer code, CONCEPT, is being developed at Oak Ridge National Laboratory to facilitate preparation of conceptual capital cost estimates for single-unit nuclear and fossil-fueled power plants. CONCEPT is written in FORTRAN IV for the IBM $360 / 65$ and requires about 160K of computer core. Running time for a single case is much less than $1 \mathrm{~min}$. A detailed cost model for PWR plants has been developed, along with the necessary cost index data and trend correlations for obtaining PWR cost estimates at various locations and future starting dates. The cost model does not include the cost of the transmission plant.

It is anticipated that CONCEPT will be of general value in AEC program planning studies. The code is meant primarily as a tool with which to examine trends and to study elements within the cost structure. Cost estimates produced by CONCEPT are not intended as substitutes for detailed cost estimates for specific projects.

\section{DESCRIPTION OF THE COMPUTER CODE}

The procedures used in the CONCEPT code are based on the assumption that any central station power plant involves approximately the same major cost components, regardless of location or date of initial operation. Therefore, if the trends of these major cost components can be established as a function of time, location, and plant type and size, a cost estimate for a reference case can be adjusted to fit the case of interest. 
The application of this approach requires a detailed cost model for each plant type at a reference condition and the determination of the cost trend relationships. The generation of these data sets comprises a large effort in the continuing development of the CONCEPT code.

The cost model is based on a detailed cost estimate for a reference plant at a designated time and location. This estimate includes a detailed breakdown of each cost account into costs for factory materials, factory labor, site materials, and site labor.

CONCEPT relies on data stored in cost index tables to adjust and project costs during the detailed calculations. Data that reflect the locational economic factors (such as labor rates and price indexes) are stored in these tables for 23 locations.

The input to the code consists of the net plant electrical capacity, plant type, plant location, date of beginning of design and construction,* date of commercial operation, length of workweek, and interest rate. Any constant, variable, or cost array stored in the code can be altered by input option. Thus contingency cases can be examined with a minimum of effort. Also, the program can be altered at execution time to take into account factors that affect the design of the plant, such as seismic problems or availability and type of heat sink. Future developments in CONCEPT will include models that automatically modify costs as a function of these and other design considerations.

As an example of the procedures described above, suppose a cost estimate for the year 1967 is available for a 1000-MW(e) net PWR plant located on a site near Middletown, ** and a cost estimate for 1975 is desired for a corresponding plant located on a similar site but near another city. The new estimate is obtained by adjusting factory and site-related costs for the Middletown plant by the ratios of the projected 1975 cost indexes for the new city to the 1967 cost indexes for Middletown.

*Beginning of design and construction is defined as the date the order is placed for the nuclear steam supply system.

**Middletown represents the USAEC standard hypothetical site described in the AEC "Guide for Economic Evaluations of Nuclear Reactor Plant Designs."I 
This technique of separating the plant cost into individual components, applying an appropriate cost index, and summing the adjusted components is the basic tool used in CONCEPT. A schematic illustration of the technique is shown in Fig. 1. This method requires four sets of cost indexes as a function of time and location. These indexes are used to adjust the costs of factory labor, site labor, factory materials, and site materials. The site and factory materials cost indexes and factory labor cost indexes are stored as data tables, but the site labor indexes are calculated from other basic parameters, which include wage rates, labor productivity, and overtime considerations. An auxiliary program is used to calculate the site materials cost indexes and site wage rates from large arrays of cost data and to generate the BLOCK DATA tables stored in CONCEPT.

Figure 2 indicates the general flow of calculations in CONCEPT. The computer code follows this procedure closely; however, the illustration is not a detailed computer program flowchart. An important feature of this arrangement is that the second, third, and sixth blocks of the diagram form the basis for different conceptual power plant calculations, and all other blocks retain their integrity. The second, third, and sixth blocks utilize internally stored data, referred to as the cost model, and these blocks are the only sections of the program that refer to the plant type. Therefore, when alternate studies are made, the majority of the program remains intact, and only the cost model for a reference plant need be added for each type of plant.

Block I. indicates the input data stream. This input is read in from FORIRAN cards and, for each case, must include the plant electrical capacity, reactor type, plant location (city and state), and design and construction period. The code will utilize certain assumptions if data are not included for the following parameters: first, the cost basis will be assumed at start of construction; second, a 40-hr workweek with no overtime will be assumed; and third, interest during construction will be based on a constant interest rate of $7 \% /$ year compounded. The cost model stored in CONCEPT is based on a hypothetical case. Cases of interest will differ from this hypothetical case, depending on what measures need to be taken 
DWG. NO. G-70-661

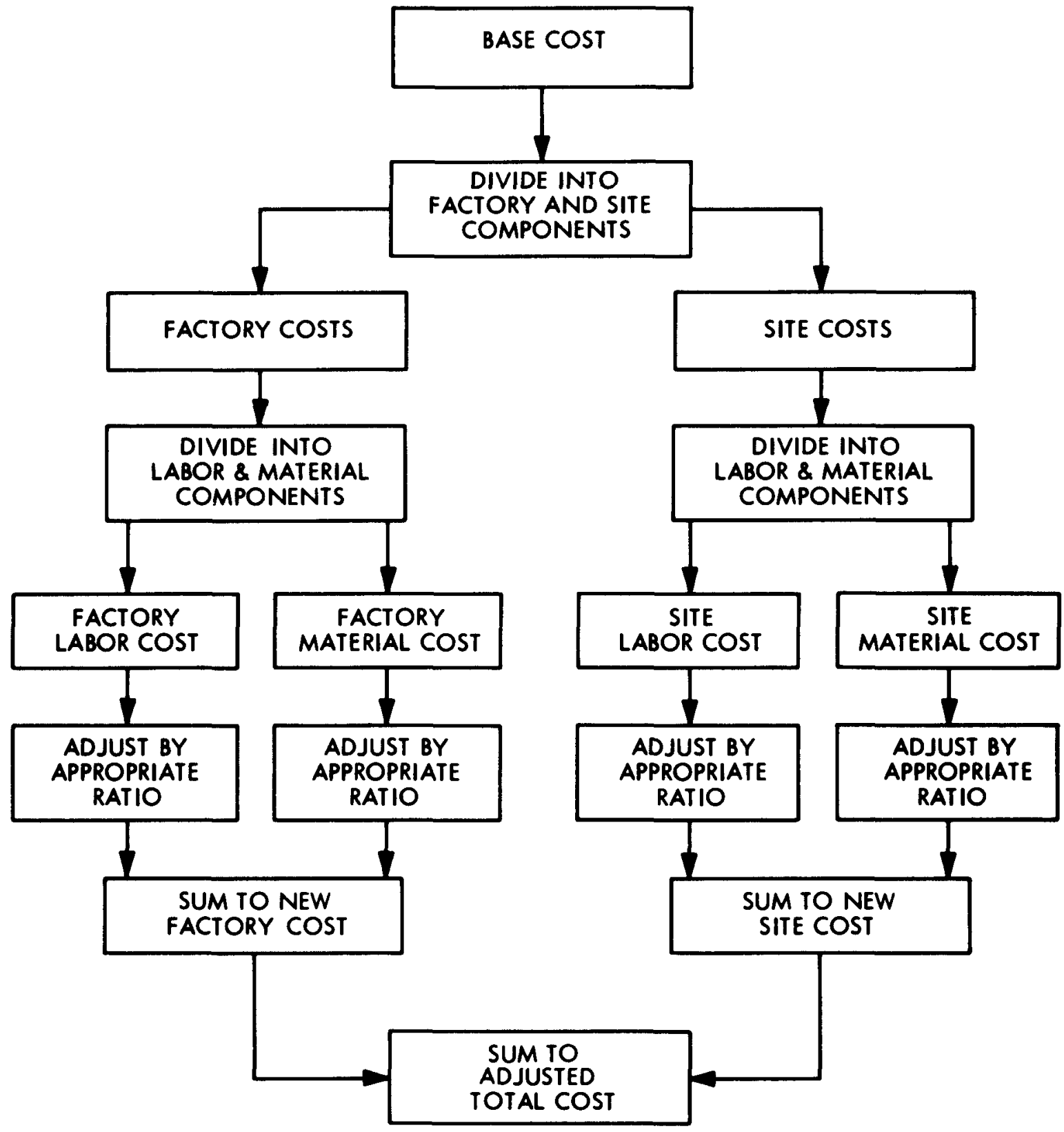

Fig. 1. Method Used to Adjust Base Costs in CONCEPT. 


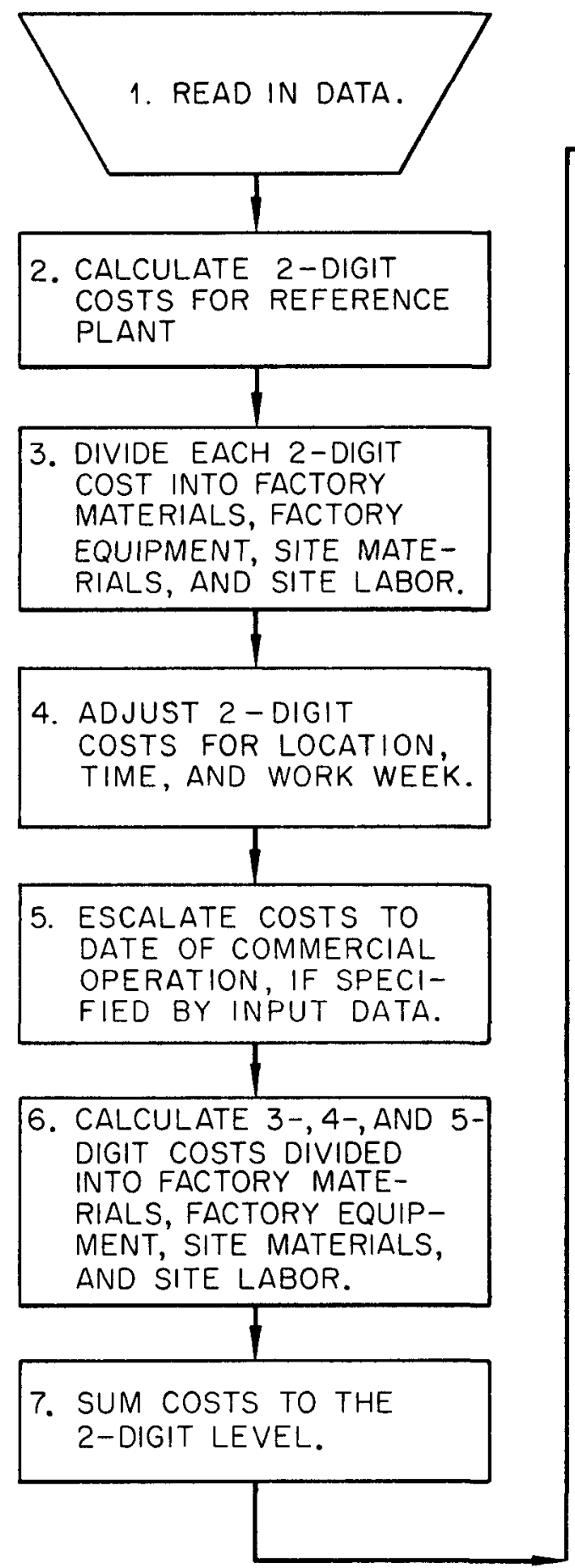

8. CALCULATE CONTINGENCIES AND SPARE PARTS.

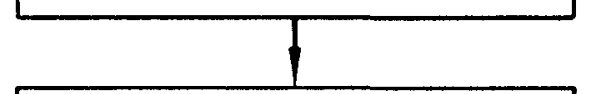

9. SUM ALL DIRECT COSTS, EXCEPT LAND AND SPECIAL MATERIALS.

10. CALCULATE INDIRECT COSTS, EXCEPT INTEREST DURING CONSTRUCTION.

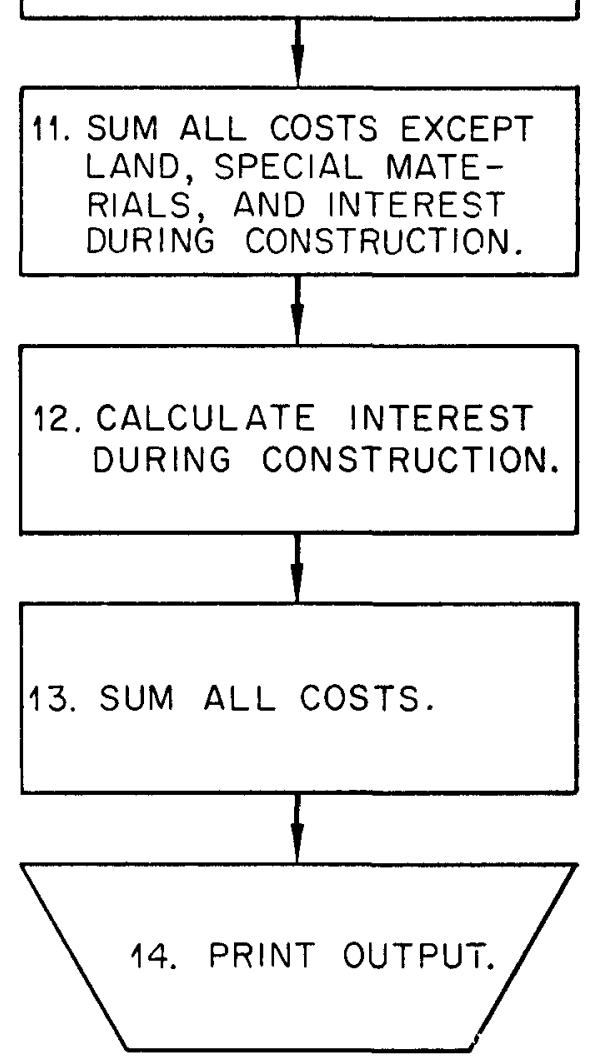

Fig. 2. CONCEPT - General Flow of Calculations. 
to establish a firm foundation, insure against earthquakes, provide for a heat sink, etc. Therefore, an input option is included in CONCEPT whereby any constant or factor in the cost model can be changed at the time of program execution. This option can also be used to alter cash flow data and cost indexes.

In block 2 an initial estimate is made for each of the two-digit direct cost accounts. These costs are calculated by using mathematical models for a reference plant that define each two-digit cost of the reference plant as a function of size: These two-digit reference costs form the basis for all costs estimated in succeeding calculations. The final cost estimates are made by adjusting and readjusting the base costs by use of cost indexes and multipliers stored in the code. The optional input feature permits the user to specify the relative magnitude of these adjustments. Most of the adjustments should be made at the three-, four-, and five-digit level of block 6 . The only changes that should be made at the two-digit level are those which affect the entire two-digit account.

In block 3 each two-digit account is divided into four components: factory materials, factory labor, site materials, and site labor. This division permits the separate adjustment and escalation of factory and site-related costs. The cost model can also be adjusted at this step to reflect differences between the reference plant and the input plant. Again, adjustments that reflect specific design changes should be made at the three-, four-, or five-digit level.

In block 4 the four components of each two-digit account are adjusted for starting date, location, and length of workweek. Costs of factory materials, factory labor, and site materials are adjusted by the ratios of the projected cost indexes for the input location and time to the cost indexes for the reference location and time. Site labor rates are corrected in a similar manner and, in addition, are adjusted for differences in productivity and overtime charges.

In block 5 the four components of each two-digit account are escalated from date of start of design and construction to date of commercial operation, if this option was specified by the input information of block 1 . This operation requires a cumulative cash flow curve for each two-digit 
account. As with most of the datin used in CONCEPT, these curves are specified by tables in the BIDCK DATA subprogram and are alterable during execution.

In block 6 the three-, four-, and five-digit costs are calculated directly from the escalated four components of the two-digit costs from blocks 4 and 5. This calculation uses stored data that allocate a fraction of each two-digit cost component to the appropriate three-digit account. Four- and five-digit accounts are similarly expressed as fractions of three- and four-digit components, respectively. It is at this level that the cost model can logically be modified to reflect design differences between the reference plant and the input plant. For example, in a high seismic risk zone, several of the four-and five-digit accounts might be adjusted to account for the extra cost of additional concrete and reinforcing steel.

In block 7 the adjusted three-, four-, and five-digit costs from block 6 are summed to the two-digit level.

In block 8 contingencies and spare parts are calculated for each two-digit account as recommended in USAEC Report NUS-531. ${ }^{1}$ These items are calculated as fractions of corresponding two-digit costs and are stored in the code, but the values can be altered at execution.

In block 9 all direct costs are summed, including contingencies and spare parts but excluding land and special materials.

In block 10 all indirect costs, except interest during construction, are calculated as recommended in USAEC Report NUS-53I. ${ }^{1}$ Costs are included for construction facilities, equipment, and services, for engineering services, and for other miscellaneous items, such as taxes and insurance during construction, staff training, plant startup, owner's general and administrative services, and allowances for licensing activities and preliminary investigations and studies. However, USAEC Report NUS-531 was published in early 1969, and it is believed that some of the cost allowances are lower than actually experienced during the past two to three years. These indirect cost allowances will be studied and revised in future versions of the code. The indirect cost data can be altered at program execution time, if desired. 
In block 11 all costs, except land, special materials, and interest during construction, are summed.

In block 12 interest during construction is calculated in three separate steps and summed: (1) interest on land, (2) interest on special materials, and (3) interest on the remainder of the direct costs and associated indirect costs based on a total cumulative cash flow curve, which is a composite of the two-digit cash flow curves of block 5 . In block 13 all costs are summed to give the total capital cost of the specified plant.

In block 14 the results are printed on the output sheets.

Figure 3 shows a typical computer output summary sheet, which gives the basic input data and ground rules for the capital cost estimate and the breakdown of direct and indirect capital costs according to the major accounts. The accounting system follows that recommended in the AEC guide for economic evaluations of nuclear reactor plant designs. ${ }^{1}$ The computer code also produces a breakdown of physical plant direct costs, including site labor requirements, at the two-digit level, as shown in Fig. 4. Other outputs include more detailed breakdowns of direct costs and indirect costs, as illustrated in Figs. 5 and 6, respectively, and the cumulative cash flow curve shown in Fig. 7 .

\section{COST MODEL FOR PWR PLANTS}

The cost model data presently used in CONCEPT are based on a detailed cost estimate (early-1970 basis) for a 1000-MW(e) PWR plant 10cated at the AEC standard hypothetical site described in Appendix A of USAEC Report NUS-531.1 This estimate includes detailed identification of factory materials, factory labor, site materials, and site labor costs. It is recognized that the hypothetical site is ideal in several respects and probably does not conform to any available new site. For example, it is assumed that condenser cooling water is available at a mean annual temperature of $57^{\circ} \mathrm{F}$ in an amount sufficient for once-through cooling, and that no cooling towers, or other special features, are required to satisfy limitations on discharge of heated water. 


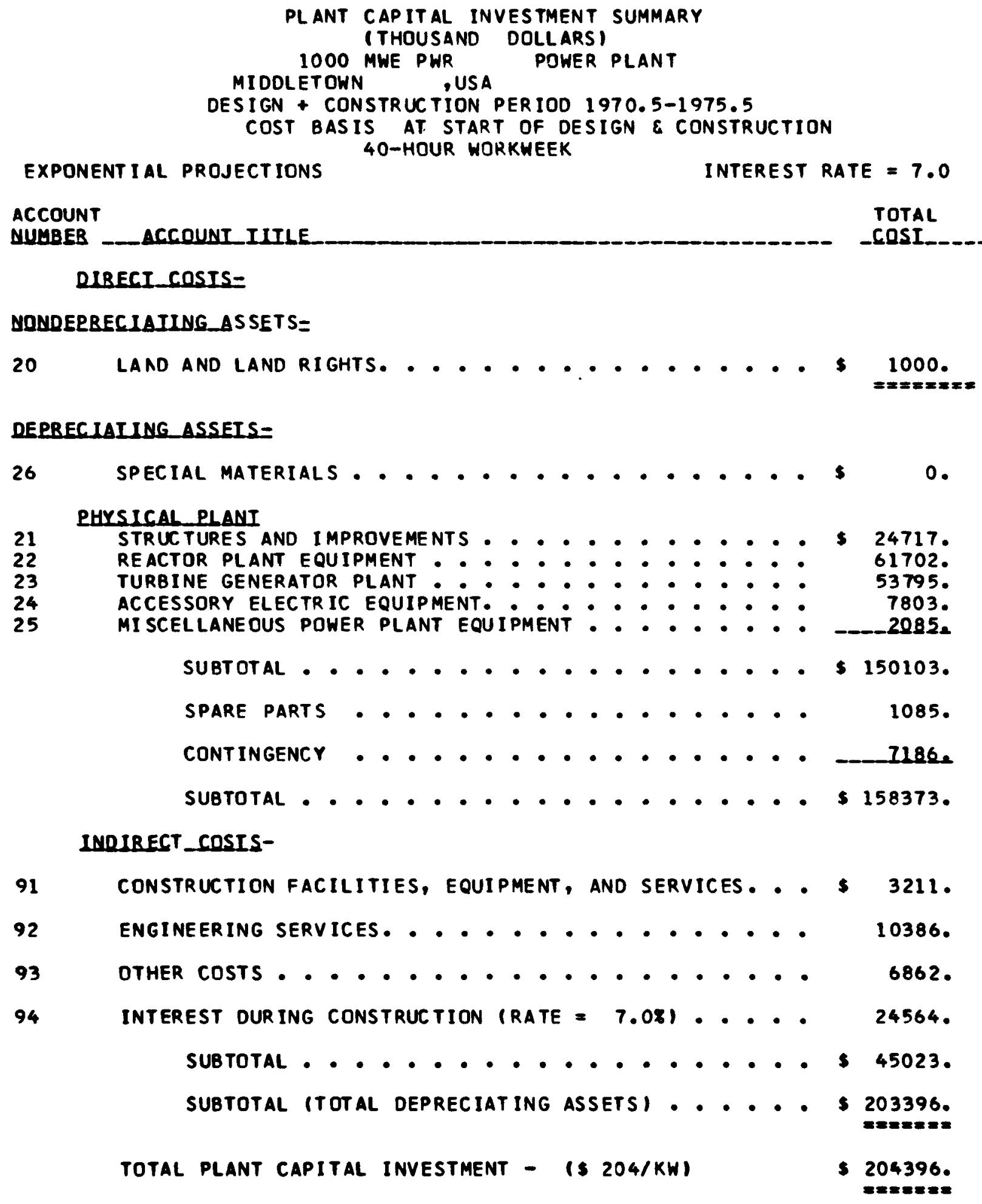

Fig. 3. Typical Computer Output Summary. 
BREAKDOWN OF PHYSICAL PLANT COSTS

\section{PHYSICAL_PLANI}

21 STRUCTURES AND IMPROVEMENTS . . . . 24717.

22 REACTOR PLANT EQUIPMENT •..... .61702.

ち
23 TURBI NE GENERATOR PLANT • • . . . . 53795.

24 ACCESSORY ELECTRIC EQUIPMENT. • • • • • 7803.

25 MISCELLANEOUS POWER PLANT EQUIPMENT • • - 2085

SUBTOTAL . . . . . . . . . 150103.
(THOUSANDS OF DOLLARS)

FACTORY EQUIPMENT

LABOR
$-\triangle C O S I$ MATERIAL

538 (1305) 11965. 12214.

46730. (1043) 9559. 5414 .

40688. ( 850) 7789. 5317 .

2440. (331) 3033. 2330 .

-1431._1__511___5232_-__-132.

91828. (3586) 32869. 25406 .

Fig. 4. Typical Computer Output - Breakdown of Two-Digit Costs. 
ACCOUNT DUMBEB -

23

231

.1

232

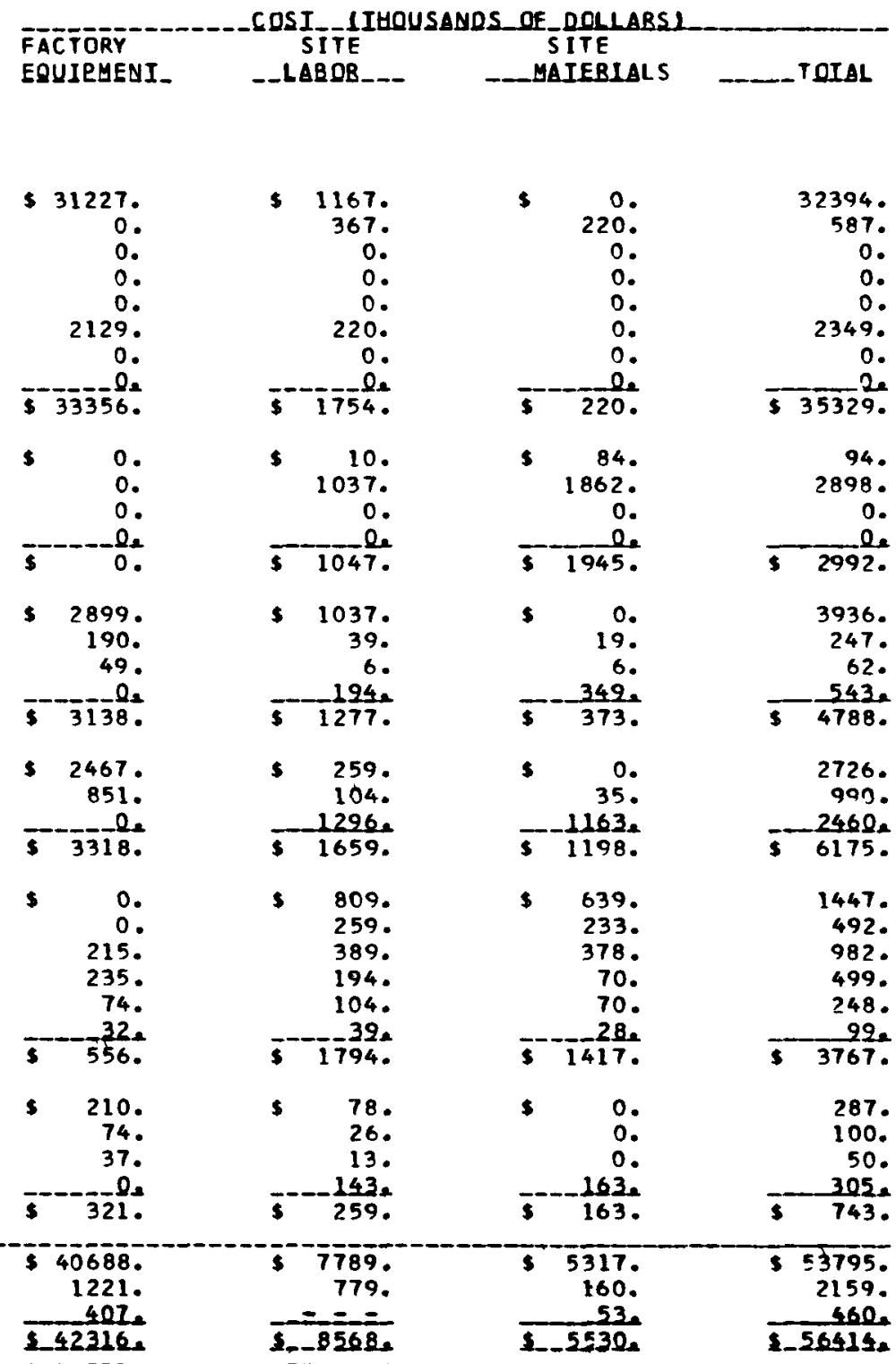

TURB INE - GENERATORS AND ACCESSORIES .......... \& 31227.

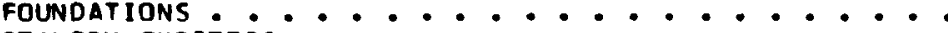

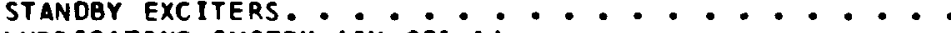

LUBRICATING SYSTEM IIN 231.1 ) $\bullet \cdot \cdot \cdot \cdot \cdot \cdot \cdot \cdot \cdot \cdot$

GAS SYSTEMS IIN $231.11 . \cdot \cdot \cdot \cdot \cdot \cdot \cdot \cdot \cdot \cdot \cdot \cdot \cdot \cdot \cdot \cdot$

SHIELDING

WEATHER -PROOF HOUSING.

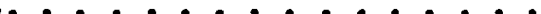

HEAT REMOVAL SYSTEMS

WATER INTAKE COMMON FACILITIESo

CIRCULATING WATER SYSTEMS

COOL ING TOWERS

OTHER SYSTEMS REJECTING HeAT TO THE ATMOSPHERE: : : : SUBTOTAL. . . . . . . . . . .

CONDENSING SYSTEMS

CONDENSERS

CONOENSATE SYSTEM

GAS REMOVAL SYSTEM.

FEED HEATING SYSTEM

REGENERATIVE HEAT EXCHANGERS

PUMPS

PIPING AND TANKS.

$$
\text { SUBTOTAL. }
$$

OTHER TURBINE PLANT EQUIPMENT

MAIN STEAM OR OTHER VAPOR PIPING

TURB INE AUXIL IARIES.

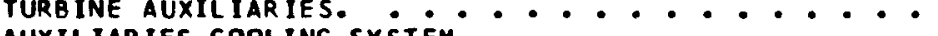

MAKEUP TREATMENT SYSTEMS.

CHEM. TREATMENT AND CONDENSATE PURIFICATION SYS

CHEM. TREATMENT AND CONDENSATE PURIFICATION SYS. : LUBRICATION SERVICE SYSTEM •

INSTR UMENTATION AND CONTROL

PROCESS I \& C EQUIPMENT

AUTO MONITORING AND RECOROING EOUIPMENT: $\bullet \cdot \bullet \cdot$

ISOLATED IND ICATING AND REC GAUGES, METERS, ${ }^{\circ} \cdot{ }^{\circ}$

CONTROL AND INSTRUMENT PIPING TUBING AND HIRING

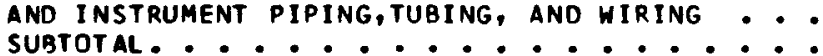

SUBTOTAL FOR ACCOUNT

CONTINGENCY ( 3 .0\%MTL-10.0\%LABOR;: : : :

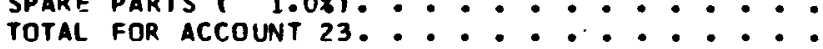

$\$ 42316$

$$
\begin{array}{r}
1167 . \\
367 . \\
0 . \\
0 . \\
0 . \\
220 . \\
0 . \\
1754 . \\
10 . \\
1037 . \\
0 .
\end{array}
$$

51047 .

$\$ 1037$.

\$ 1277 .

259.

$-1296$

809.

259.

389.

Fig. 5. Typical Computer Output - Three- and Four-Digit Levels. 
ACCOUNT NUMBEB

CONSTRUCTION FACILITIES, EQUIPMENT, AND SERVICES

911

TEMPORARY FACILITIES.

$\cdot \cdot \cdot \cdot \cdot \cdot \cdot \cdot \cdot \cdot \cdot$

CONSTRUCTION SERVICES

TOTAL FOR ACCOUNT 91...............

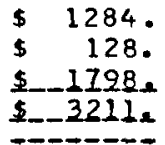

92

ENGINEER ING SERVICES

921

REACTOR ENGINEER ING

922

PLANT ENGINEER ING

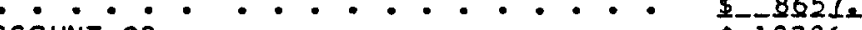
TOTAL FOR ACCOUNT 92............... \$10386.

93

OTHER COSTS

931

932

TAXES AND INSURANCE

STAFF TRAINING AND PLANT STARTUP.............. $\$ 1189$.

933

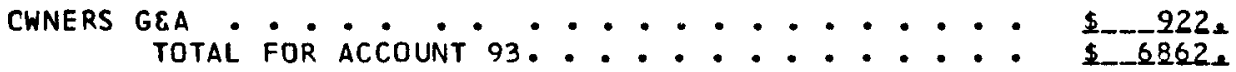

94

INTEREST DURING CONSTRUCTION

941

942

Physical Plant and associated IndiRect COSTS. . - . -

$\$ 24063$.

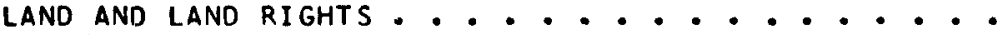

$\$ 501$.

943

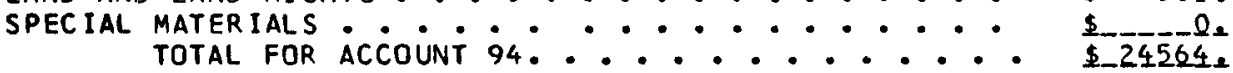

Fig. 6. Typical Computer Output - Indirect Costs. 


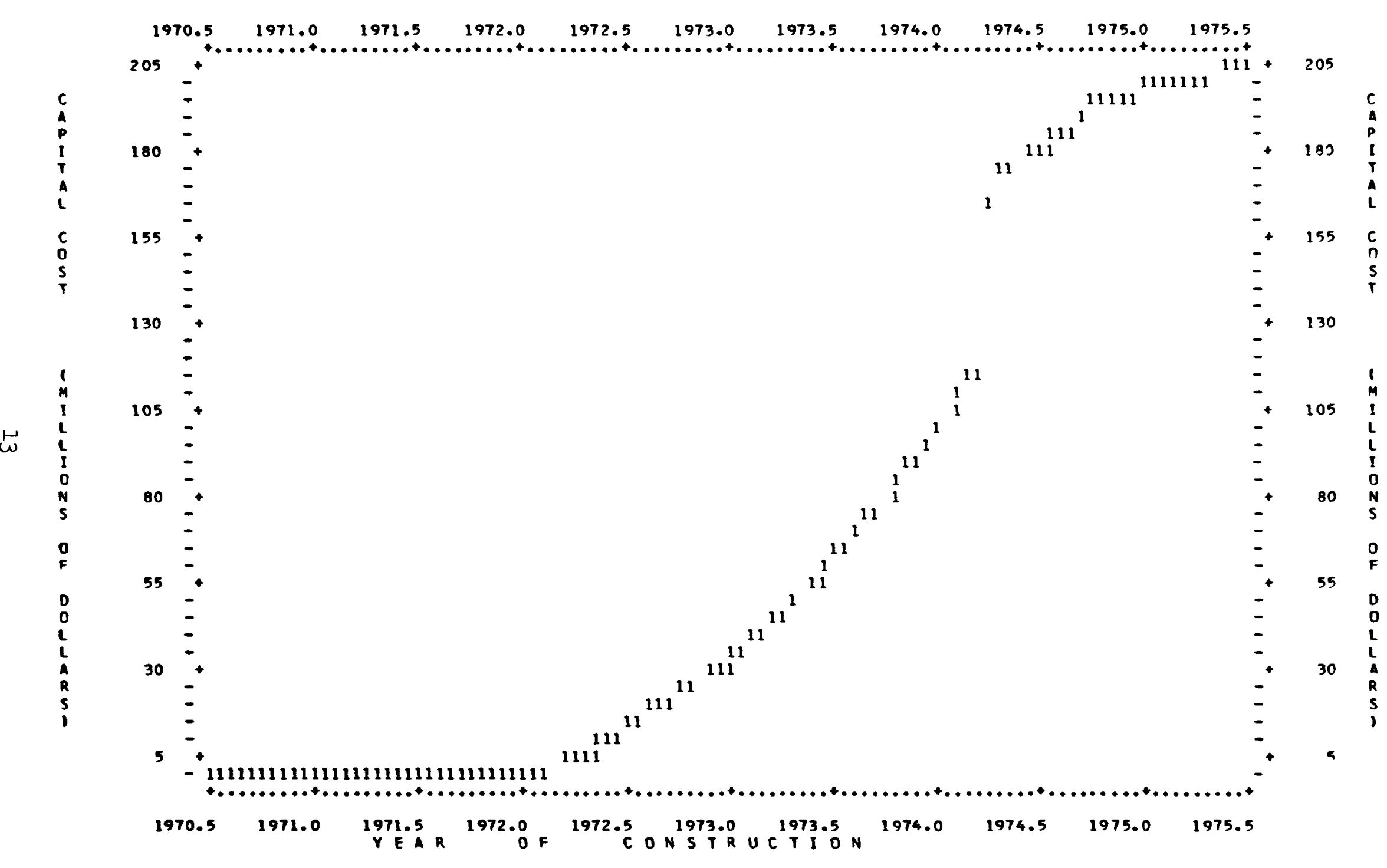

Fig. 7. Typical Cumulative Cash Flow Curve. 
The two-digit direct costs for the 1000-MW(e) plant are extrapolated to those for similar PWR plants of other size by equations that describe the costs shown in Fig. 8. All equations are of the form,

$$
Y_{i}=A_{i}+B_{i} X^{C_{i}}
$$

where $i$ identifies each two-digit account, $Y_{i}$ is the two-digit direct cost in thousands of dollars, $X$ is the plant net electrical capacity in $M W(e)$, and $A_{i}, B_{i}$, and $C_{i}$ are constants. These constants are stored in the BLOCK DATA subprogram and can be altered through the input data stream. The curves and equations shown in Fig. 8 are representative of capital costs for unit sizes from $300 \mathrm{MW}(\mathrm{e})$ to about $1200 \mathrm{MW}(\mathrm{e})$. Above $1200 \mathrm{MW}(\mathrm{e})$, cost trends were extrapolated, and the equations should not be used outside the range 300 to $2000 \mathrm{MW}(\mathrm{e})$. The increasing slopes for the cost trend curves for Accounts 21 and 23 reflect decreasing economy of scale as unit size is increased.

Each total two-digit direct cost is divided proportionately into factory materials, factory labor, site materials, and site labor components by the fractions shown in Fig. 9, which were developed from the detailed cost estimate. As an illustration, this model allocates about $30 \%$ of the total 22 Account (Reactor Plant Equipment) to factory materials, about $46 \%$ to factory labor, about $9 \%$ to site materials, and about 15\% to site labor. These percentages are assumed to be independent of plant size in the present cost model, but will be varied with size in future versions of the code.

The detailed calculation of escalation during construction uses cash flow curves of the type illustrated in Fig. 10 for each two-digit account. These cash flows are assumed to be approximately the same for all PWR-type power plants and, like the other important parameters, can be changed with the optional input feature. The curves are normalized along both axes to vary between zero and 100\%; this normalization should simplify studies where construction periods and cash flows are altered concurrently. The origin corresponds to date of placing the order for the nuclear steam supply system. Approximately $30 \%$ on the abscissa corresponds to date of issuance of construction permit and start of actual 


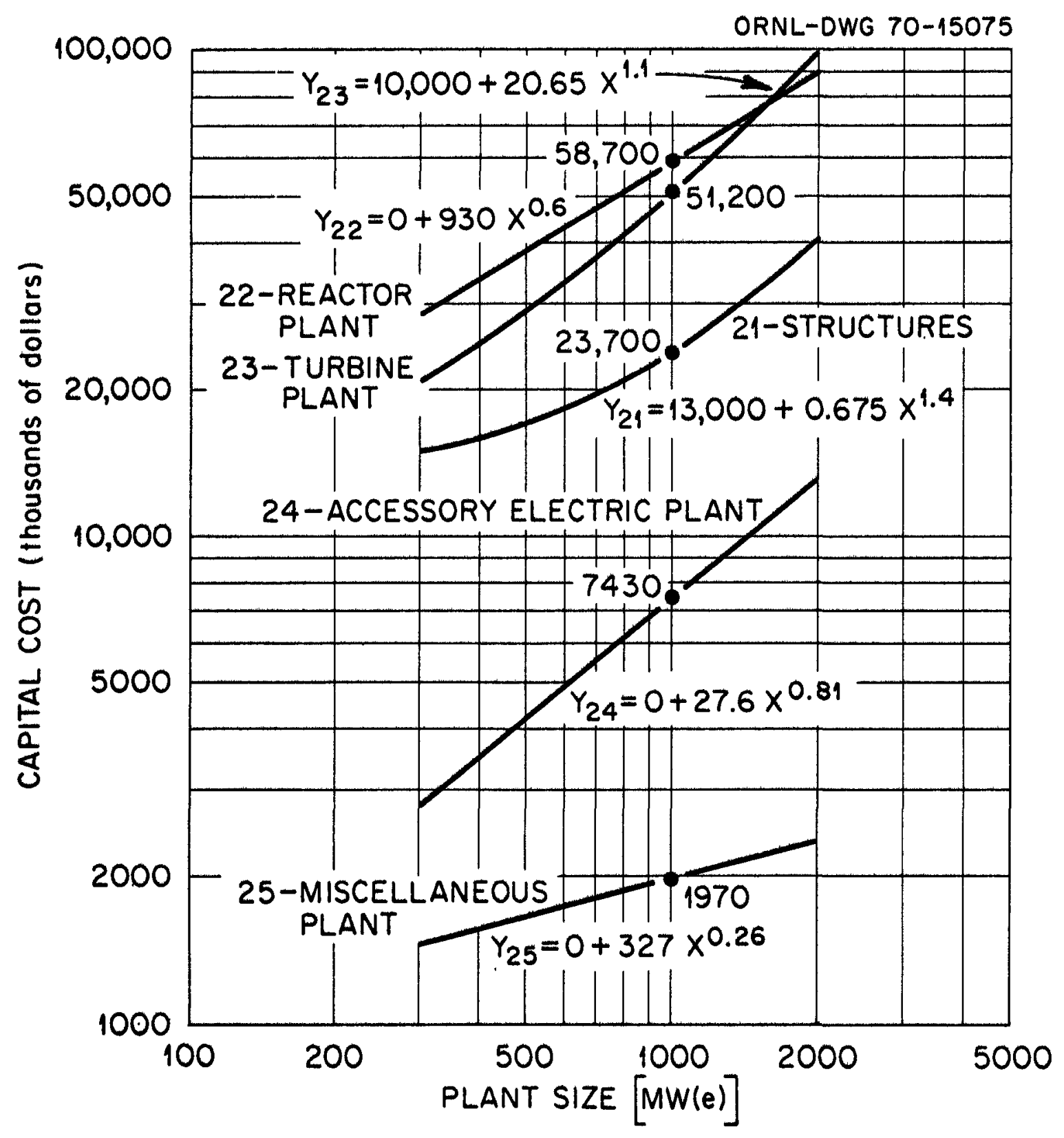

Fig. 8. Physical Plant Direct Costs for PWR Plants (Early 1970 Basis). 
THIS ARRAY SPLITS EASE COST INTO 2-DIGIT COST CONPONEITS.

FACTORY

MATERIAL

. 0

.01094

.30410

.37857

.15614

.34445

1.0
FACTORY SITE

$\angle A B O R$

SITE

$\angle A B O R$

ACCNUNT

- - - - -

20

21

22

23

24.

25

26

Fig. 9. PWR Cost Model Constants for Dividing Two-Digit Direct Costs into Factory Material, Factory Labor, Site Material, and Site Labor. 


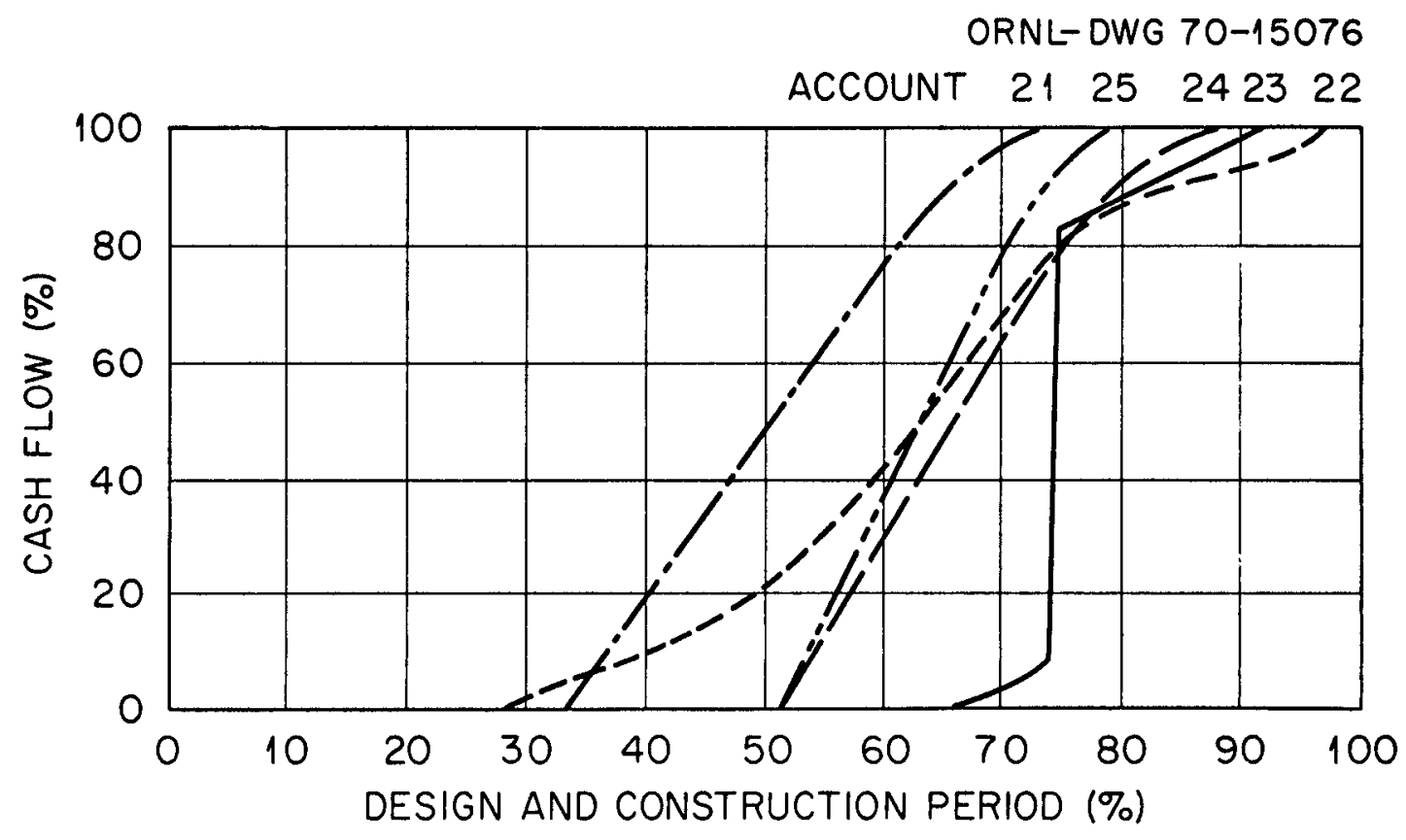

Fig. 10. Two-Digit Account Cash Flow Curves. 
construction, and $100 \%$ corresponds to date of commercial operation. The total cash flow curve shown previously in Fig. 7 was developed from these two-digit cash flow curves and is used for calculation of interest during construction.

The more detailed three-, four-, and five-digit costs are calculated in a manner similar to the decomposition of the two-digit costs; again, cost model constants developed from the detailed reference cost estimate are used. Figure 11 shows typical cost model constants at the threedigit level for Account 22 (Reactor Plant Equipment). Each of the four components of the two-digit account is allocated to the three-digit accounts by the fractions shown. For example, Fig. 11 allocates about $34 \%$ of the total 22 Account factory materials to Account 221 (Reactor Equipment) $47 \%$ to Account 222 (Main Heat Transfer and Transport System), and so on. These constants are stored in the BIOCK DATA subprogram and can be changed at problem execution time to reflect differences in design features between the input plant and reference plant.

\section{COST INDEXES}

Figure 12 shows an example of the cost index tables presently stored in the BIOCK DATA subprogram for the AEC standard hypothetical site. There are ten columns in each table. The first two columns identify the state and the city. The hypothetical site is assumed to be located in the northeastern part of the U.S. near Albany, New York, and cost indexes for Boston, Massachusetts, are assumed to be applicable.

The years associated with the cost index numbers are also tabulated in column 2 following the name of the city. Future versions of the code will include approximately ten years of historical cost index data.

The two-digit account numbers are tabulated next in column 3 . Different sets of index numbers can be stored for each two-digit account; however, in the present model the indexes for the five two-digit accounts are assumed to be the same.

Hourly rates for common and skilled site labor, including fringe benefits, are listed in columns 4 and 5 . The rates for common labor are for the heavy construction classification reported by Engineering News- 
THIS ARRAY SPLITS 2-DIGIT COST CONPONENTS INTO 3-DIGIT COST COMPONENTS.

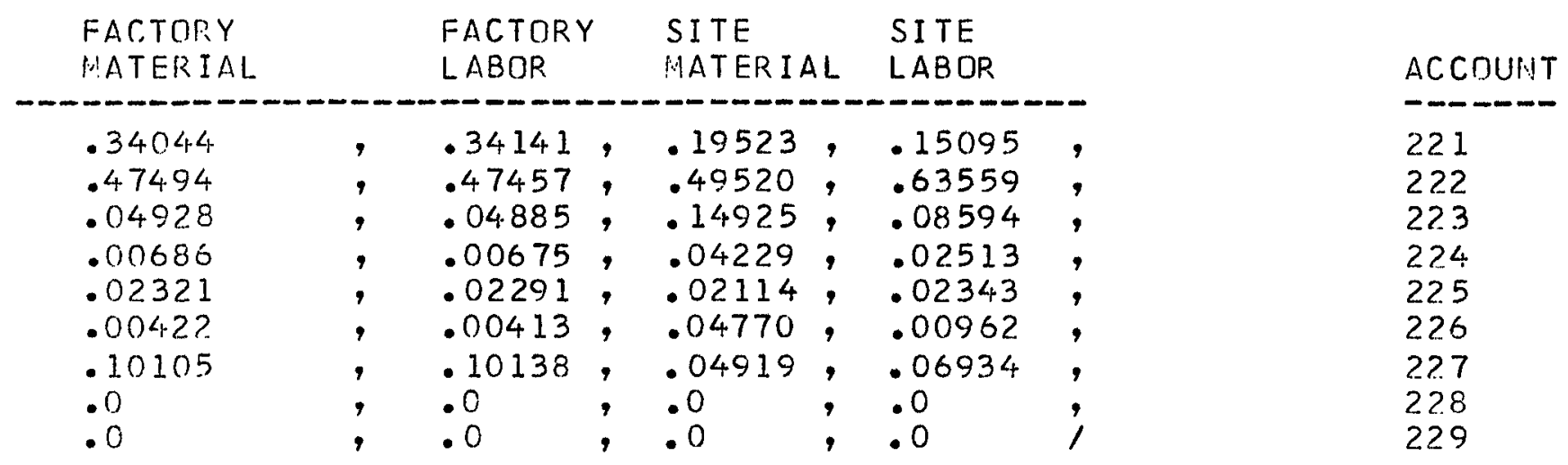

F1g. 11. Typical PWR Cost Model Constants for Allocating Account 22 Cost Components to the Three-Digit Accounts. 
(1)

STATE
(2)

(3)

CITY $\varepsilon$ YEAR

USA MIDOLFTOWN 1967.5 ,

1968.5 ,

1969.0 ,

1969.5 ,

1970.0 ,

1970.5 ,

1967.5 ,

1968.5 ,

1969.0 ,

1969.5 ,

1970.0 ,

1970.5 ,

1967.5 ,

1968.5 ,

1969.0 ,

1969.5 ,

1970.0 ,

1970.5 ,

1967.5 ,

1968.5 ,

1969.0 ,

1969.5 ,

1970.0 ,

1970.5 ,

1967.5 , 1968.5 ,

1969.0 ,

1969.5 ,

1970.0 ,

1970.5 ,
(4) (5)

(6)

(7)

(8)

(9)

(10)

ACC SITE LABOR SITF SITE FACT FACT FACT COMMON SKILL PROD. MTL LAROR PROD MTL FACTOR

FACTOR
22

4.00 ,

4.17 ,

4.35,

4.57,

4.60 ,

5.42 ,

4.00

4.17

4.35,

4.57 ,

4.60 ,

5.42 ,

23

4.00 ,

4.17 ,

4.35,

4.57 ,

4.60 ,

5.42 ,

24

25

4.00 ,

4.17 ,

4.35,

4.57,

4.60 ,

5.42 ,

$5.80,0.80$,

$6.22,0.75$,

$6.46,0.73$,

$6.68,0.71$,

$6.88,0.69$,

7.35 ,

0.67 ,

$5.80,0.80$,

$6.22,0.75$,

$6.46,0.73$,

$6.68,0.71$,

$6.88,0.69$,

$7.35,0.67$,

$5.80,0.80$,

$6.22,0.75$,

$6.46,0.73$,

$6.68,0.71$,

$6.88,0.69$,

$7.35,0.67$,

$5.80,0.80$,

$6.22,0.75$,

$6.46,0.73$,

$6.68,0.71$,

$6.88,0.69$,

$7.35,0.67$,

$4.00,5.80,0.80$,

$\begin{array}{ll}5.80, & 0.80, \\ 6.22, & 0.75,\end{array}$

$6.46,0.73$,

$6.68,0.71$,

0.89 ,

0.96 ,

1.00 ,

1.04 ,

1.00 ,

0.99 ,

0.96 ,

1.00 ,

1.04 ,

1.00 ,

0.99 ,

0.89 ,

0.96 ,

1.00 ,

1.04 ,

1.00 ,

0.99 ,

0.89 ,

0.96 ,

1.00 ,

1.04 ,

1.00 ,

0.99 ,

0.89 ,

0.96 ,

1.00 ,

1.04 ,
0.89 , $\begin{array}{lllll}4.60, & 6.88, & 0.69, & 1.00, & 3.17,1.00,1.16, \\ 5.42, & 7.35,0.67, & 0.99, & 3.32,1.00,1.221\end{array}$

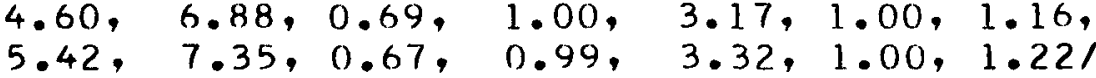

$2.77,1.00,1.03$, $2.91,1.00,1.08$, $3.03,1.00,1.09$, $3.08,1.00,1.13$, $3.17,1.00,1.16$, $3.32,1.00,1.22$,

$2.77,1.00,1.03$, $2.91,1.00,1.08$, $3.03,1.00,1.09$, $3.08,1.00,1.13$, $3.17,1.00,1.16$, $3.32,1.00,1.22$,

$2.77,1.00,1.03$, $2.91,1.00,1.08$, $3.03,1.00,1.091$ $3.08,1.00,1.13$, $3.17,1.00,1.16$, $3.32,1.00,1.22$,

$2.77,1.00,1.03$, $2.91,1.00,1.08$, $3.03,1.00,1.09$, $3.08,1.00,1.13$, $3.17,1.00,1.16$, $3.32,1.00,1.22$,

Fig. 12. Cost Index Array for AEC Reference Site. 
Record $^{2}$ in their monthly market quotations. The rates for skilled labor are equally weighted averages of the rates for the six skilled building trades (bricklayers, carpenters, structural ironworkers, plasterers, electrical workers, and steam fitters) also reported by Engineering NewsRecord.2 In cities where shorter workweeks are in effect, hourly rates have been adjusted to a 40-hr week. In future versions of CONCEPT, wage rates will be adjusted for the actual distribution of crafts in each account for each type of plant.

Site labor productivity factors, based on a 40-hr week, are tabulated in column 6. Productivity factors are often vague and difficult to define and, in practice, can vary considerably within a single locale, depending on factors such as the general economy, project supervision, labor relations, job conditions, equipment availability, and the weather. The productivity factors tabulated here indicate a decrease in site labor productivity of approximately 6\% per year from 1967 to 1969 and a decrease of about $4 \%$ from 1969 to 1970 .

The site materials index factors tabulated in column 7 were developed from the monthly market quotations for materials reported by Engineering News-Record $^{2}$ based on the following materials for a 1000-MW(e) PWR plant:

$\begin{array}{lc}\text { Structural steel } & 10,000 \mathrm{lb} \\ \text { Reinforcing bars } & 20,000 \mathrm{lb} \\ \text { Concrete } & 115 \mathrm{yd}^{3} \\ \text { Plyform } & 2,500 \mathrm{ft}^{2} \\ 2 \times 4 \text { lumber } & 6,500 \mathrm{bd}-\mathrm{ft}\end{array}$

This is a typical mixture of materials for the total PWR plant and has been used in calculating materials indexes for all cities. Such mixtures are expected to vary with reactor type, size, location, and account number. The mixture will be arranged as an input option in future versions of the code.

The cost index numbers shown in columns 8, 9, and 10 are associated with the cost of factory equipment. The factors for factory labor tabulated in column 8 are based on average hourly earnings in the electrical equipment industry (SIC 36) as reported in Monthly Labor Review. ${ }^{3}$ Changes in productivity of factory labor have not been considered, and 
the productivity factors in column 9 are assumed to be constant for all time periods. The factors for factory materials tabulated in column 10 are based on wholesale price indexes for steel mill products (Code 1013), as reported in Monthly Labor Review.

At present there is no regional or city-to-city adjustment of costs of manufactured equipment. This assumption may be valid for a first approximation, since transportation costs usually are a small part of the total cost of the plant. However, as the cost model is refined, regional differences will be considered, and cost adjustment factors will be included as they are developed.

Similar cost index arrays are stored in the BLOCK DATA subprogram for the 20 cities shown on the map of the United States in Fig. 13. Cost index data are also stored for two cities in Canada, Montreal and Toronto. These are the 22 cities for which construction labor rates and site materials costs are reported monthly in Engineering News-Record. ${ }^{2}$ Cost index data for other locations can also be entered into the BLOCK DATA subprogram.

The data in these cost index tables are used for adjusting capital costs at the AEC reference site to costs at any of the other 22 cities and for escalating costs along the time axis. The computer code extrapolates the historical cost index data into the future by either of the following equations:

$$
\begin{aligned}
& \mathrm{P}_{1}=\mathrm{a}+\mathrm{b} \Delta \mathrm{t}, \\
& \mathrm{P}_{2}=\alpha \beta^{\Delta \mathrm{t}} .
\end{aligned}
$$

The constants $a, b, \alpha$, and $\beta$ are determined by regression analysis of the historical cost index data, and $\Delta t$ is an incremental time change. A comparison of projections of skilled labor rates for the Middletown site based on these two equations is shown in Fig. 14. Curves were fit to the historical data for six points, 1967.5, 1968.5, 1969.0, 1969.5, 1970.0, and 1970.5, and extrapolated to 1980. The linear projection, Eq. (2), gives the lower estimate for the future, about $\$ 12 / \mathrm{hr}$ for 1980 , which might serve as a lower bound. The exponential projection, Eq. (3), gives an estimate of about $\$ 14 / \mathrm{hr}$ for 1980 and appears to fit the historical data more accurately. 


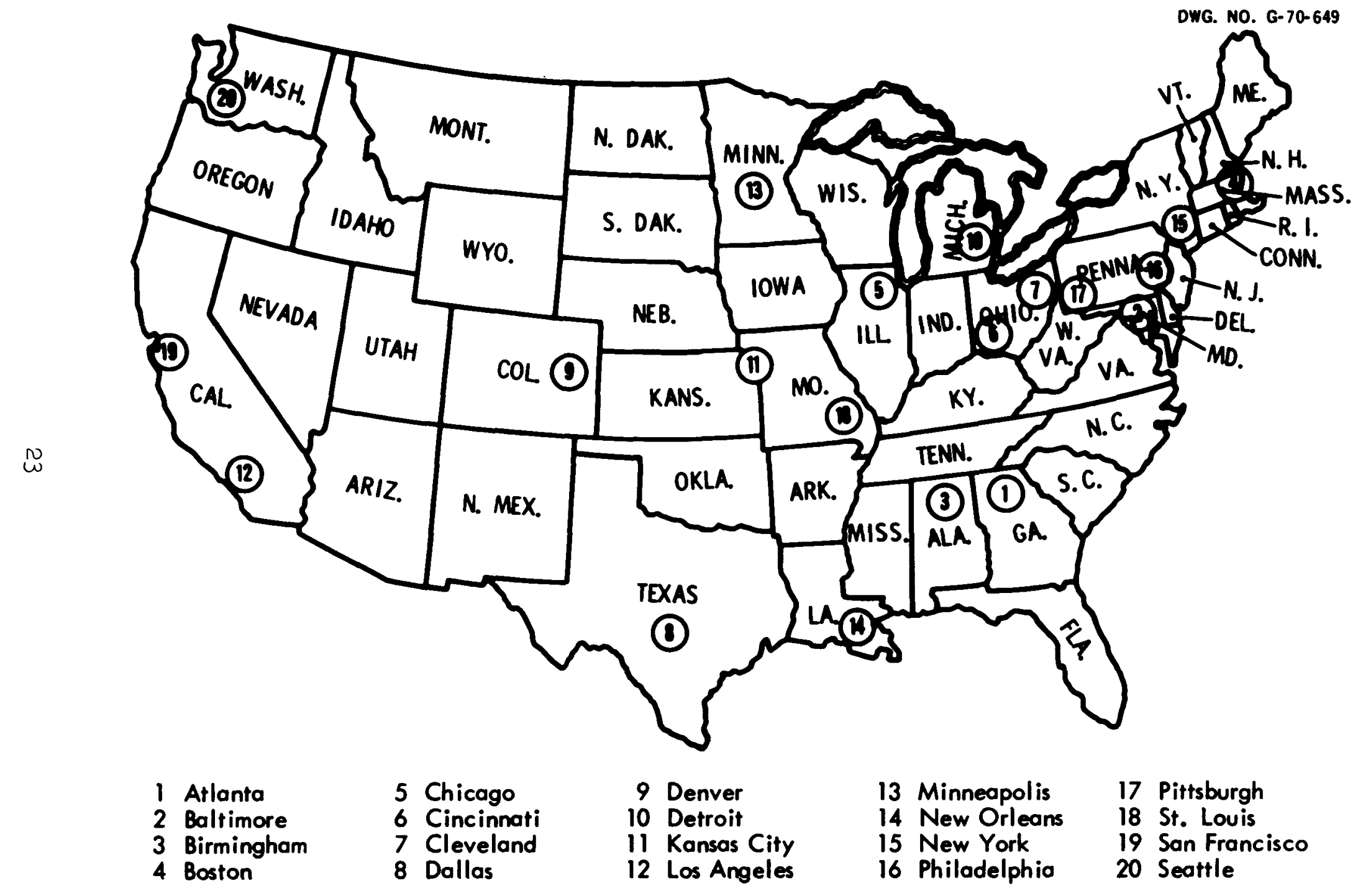

Fig. 13. Twenty U.S. Cities for Which Data Are Stored in CONCEPT. 


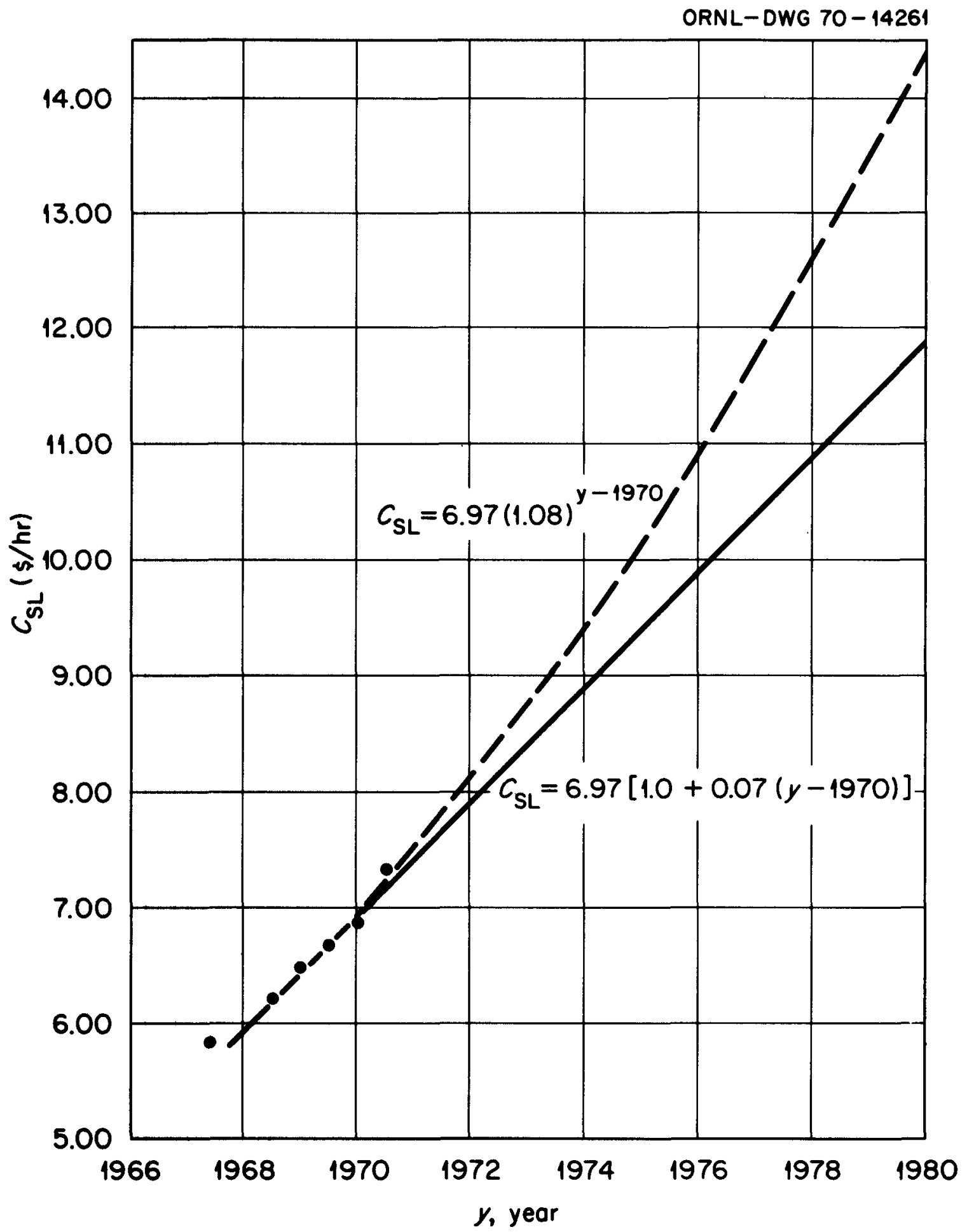

Fig. 14. Projections of Skilled Labor Rates for Middletown Site. 
Figure 15 shows an estimate of the effects of sustained overtime on the efficiency, or productivity, of site labor. The lower curve is stored in CONCEPT in equation form and is used to adjust labor cost indexes when overtime is specified. Discussions with construction management people indicate that sustained overtime is effective only for a few weeks and that extended overtime is extremely inefficient. For example, Fig. 15 shows the average number of productive hours for a 54-hr week (six 9-hr days), when compared with a 40-hr week, to be about $46 \mathrm{hr}$, an increase of $6 \mathrm{hr}$ of productive labor for 14 additional hours at work. At double pay for overtime, this is $6 \mathrm{hr}$ of productive labor for $28 \mathrm{hr}$ additional pay. Even this estimate may be optimistic; a study reported by Electrical World shows a loss in productivity after seven weeks and a net overall loss to the job after 16 weeks of sustained overtime. 4

\section{EXAMPIE CALCULATIONS}

The results of several examples of cost calculations made with CONCEPT are discussed in the following paragraphs. All cost estimates are for PWR plants at start of design and construction* based on the cost model and methods just described. Escalation during the design and construction period to date of commercial operation is not included. For an overall escalation rate of $6 \%$ per year and a five-year design and construction period, this factor alone can increase final costs at date of commercial operation by about $20 \%$. This amounts to over $\$ 40$ million for a 1000-MW(e) PWR plant.

Examples of linear and exponential projections of costs for five cities are shown in Figs. 16 and 17, respectively. For linear extrapolation, estimated costs for the AEC reference site (Middletown) increase from about $\$ 200 / \mathrm{kW}(\mathrm{e})$ in 1970 to about $\$ 310 / \mathrm{kW}(\mathrm{e})$ in 1980 and, for exponential extrapolation, from about $\$ 200 / \mathrm{kW}(\mathrm{e})$ to about $\$ 360 / \mathrm{kW}(\mathrm{e})$. Four of the five cost projections remain close together over the time interval, whereas the costs for New York City tend to diverge upward. This

* Start of design and construction is defined as the date that the order is placed for the nuclear steam supply system. 

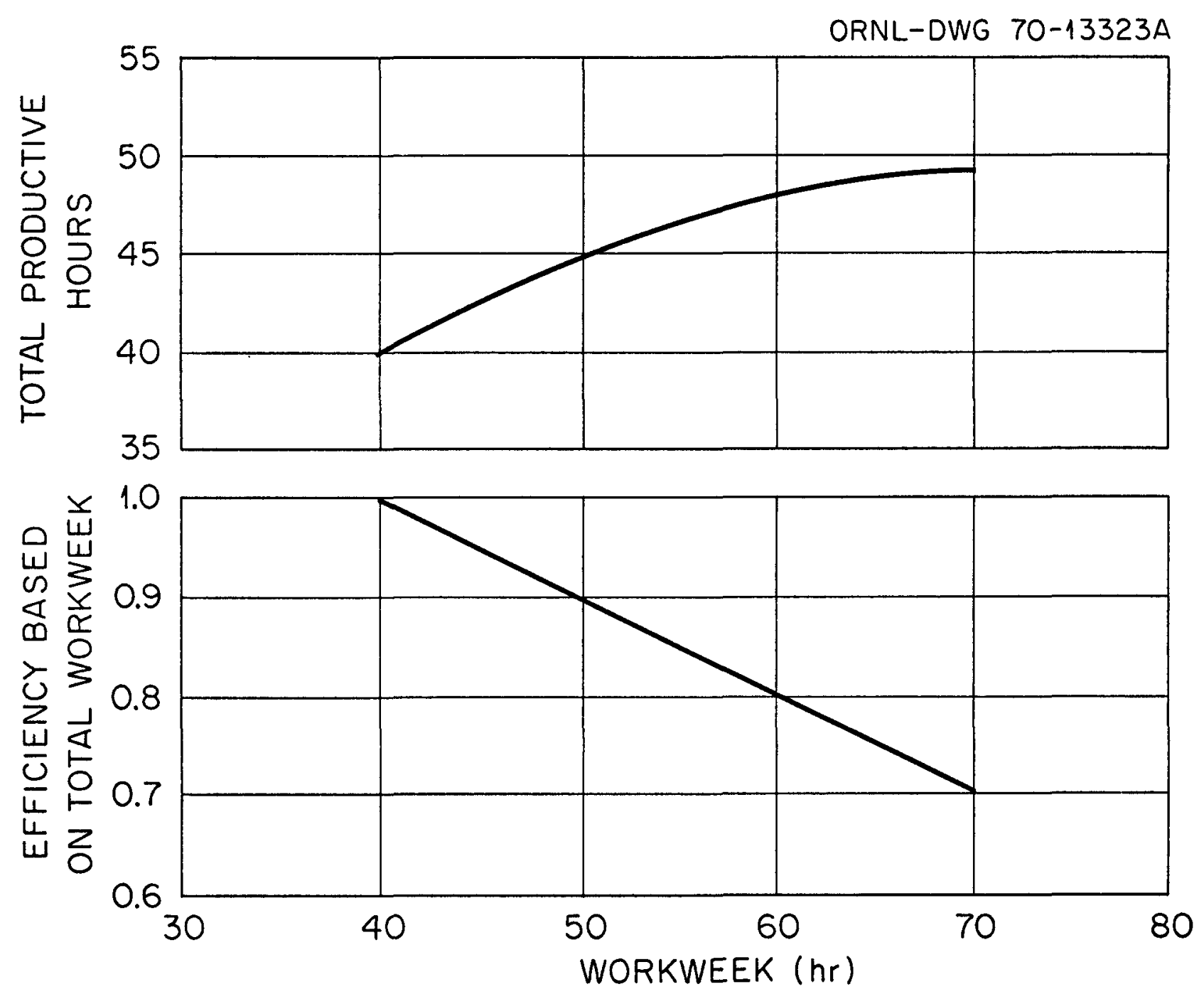

Fig. 15. Effects of Sustained Overtime on Productivity of Site Labor. 


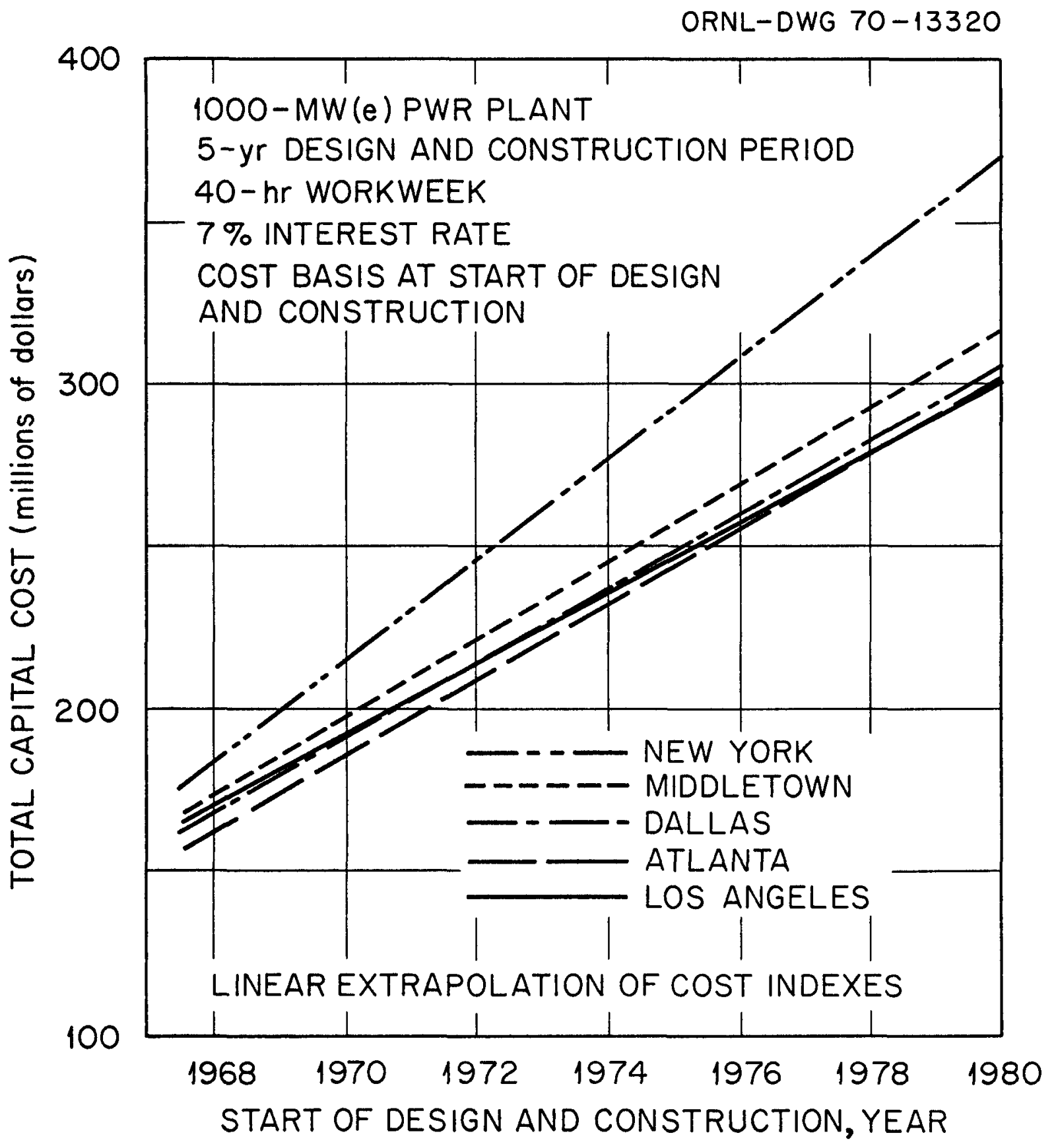

Fig. 16. Linear Extrapolation of Capital Costs of PWR Plants in Five Cities as a Function of Year of Start of Design and Construction. 
ORNL-DWG $70-13318$

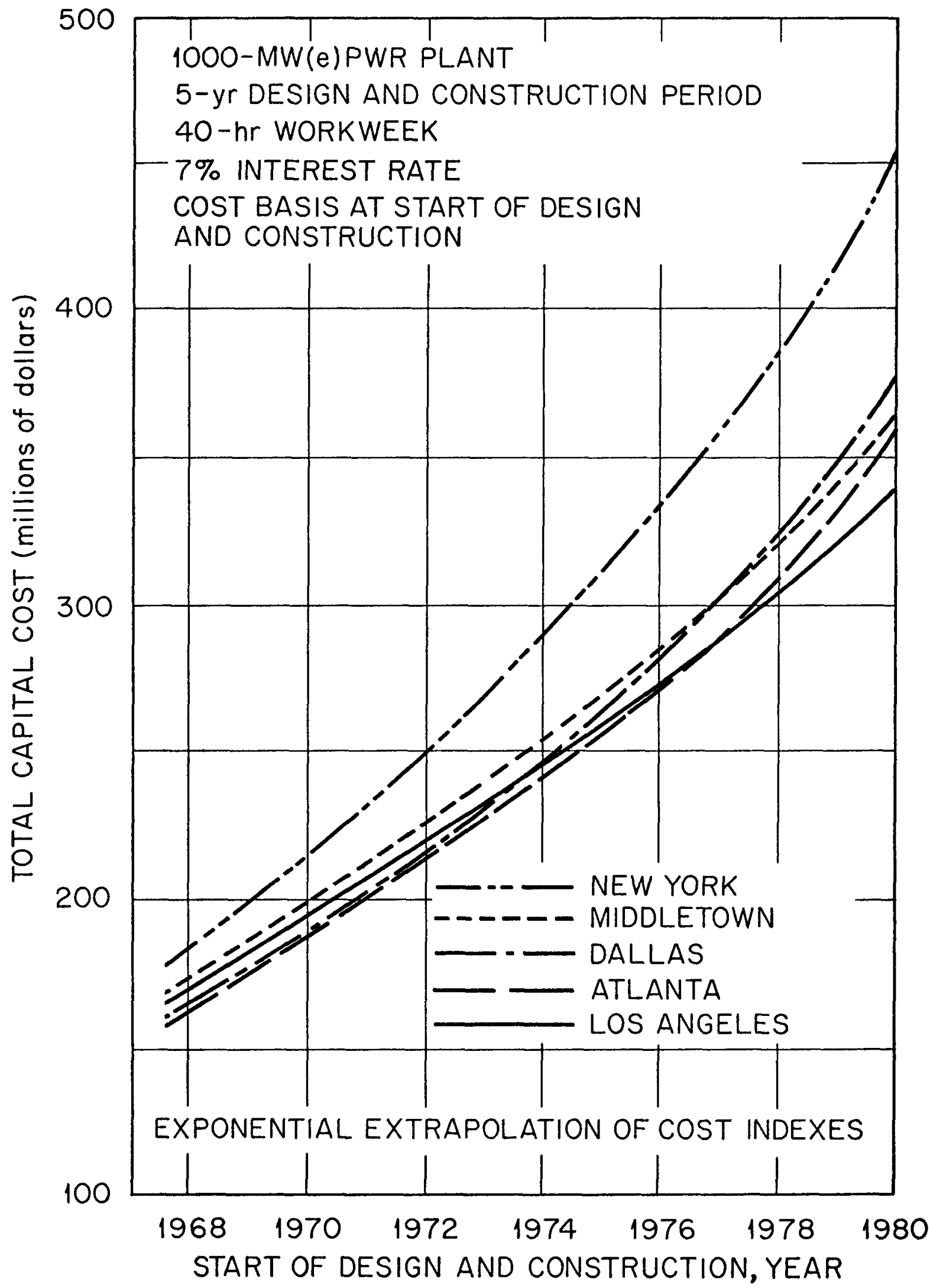

Fig. 17. Exponential Extrapolation of Capital Costs of PWR Plants in Five Cities as a Function of Year of Start of Design and Construction. 
divergence is the result of considering only the immediate area cost trends. A method is being studied whereby the projections can be weighted by regional and national trends as estimates are extended far into the future.

Figure 18 shows total capital cost of the Middletown plant as a function of size or plant electrical rating. Estimated costs range from about $\$ 270 / \mathrm{kW}(\mathrm{e})$ for the 500-MW(e) plant to about $\$ 200 / \mathrm{kW}(\mathrm{e})$ for the 1000-MW(e) plant and have been extrapolated to about $\$ 185 / \mathrm{kW}(e)$ for the $1500-\mathrm{MW}(\mathrm{e})$ plant and to about $\$ 170 / \mathrm{kW}(\mathrm{e})$ for the $2000-\mathrm{MW}(\mathrm{e})$ plant. All plants were assumed to be single-unit plants, including the 1500- and 2000-MW(e) plants.

Figure 19 shows total capital cost of the Middletown plant as a function of design and construction period. The effect is about $\$ 5$ million for each year change in the design and construction period. The cost difference shown here is entirely due to the variation in interest during construction. This analysis is based on an ideal stretchout of the construction schedule over the total construction period. The effect can be much greater, amounting to more than $\$ 1$ million each month, if plant operation is delayed near the end of the construction project at a time when most of the construction funds have been expended. It is also recognized that escalation and certain fixed costs, such as construction facilities, also vary with the change in design and construction period and should be taken into account.

Figure 20 shows total capital cost of the Middletown plant as a function of length of workweek for construction labor. The effects of extended overtime, assuming the productivity shown previously in Fig. 15 and a constant design and construction period of five years, are to increase costs by about $\$ 8$ million for a $45-\mathrm{hr}$ week, about $\$ 13$ million for a 48-hr week, and about $\$ 20$ million for a 54-hr week. This analysis does not take into account potential savings in interest during construction due to shortening the construction period.

Figure 21 shows total capital cost of the Midaletown plant as a function of interest rate for a constant design and construction period of five years. The effect is about $\$ 4$ million for each $1 \%$ change in the interest rate. 


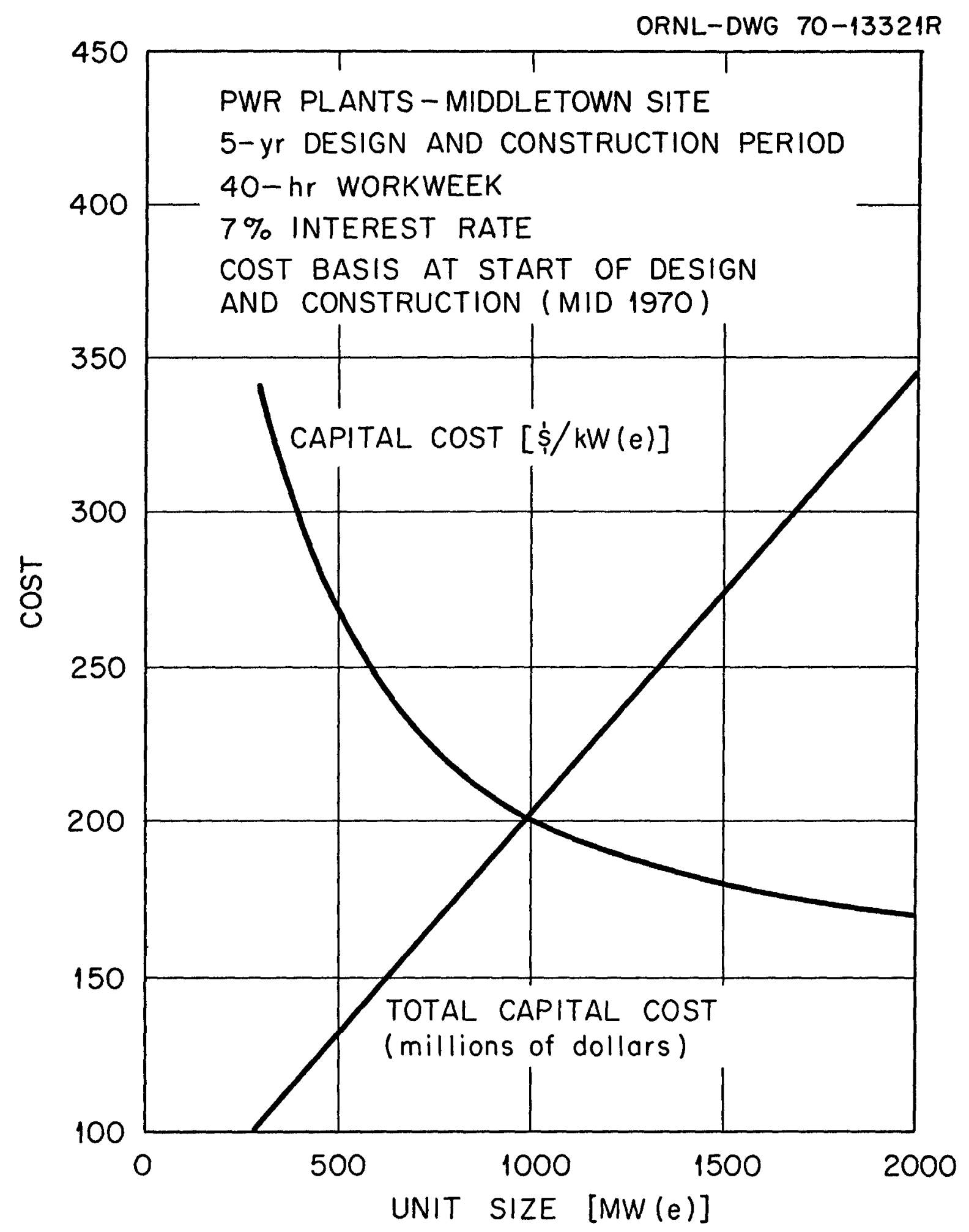

Fig. 18. Capital Cost as a Function of Unit Size. 
ORNL-DWG 70-13322

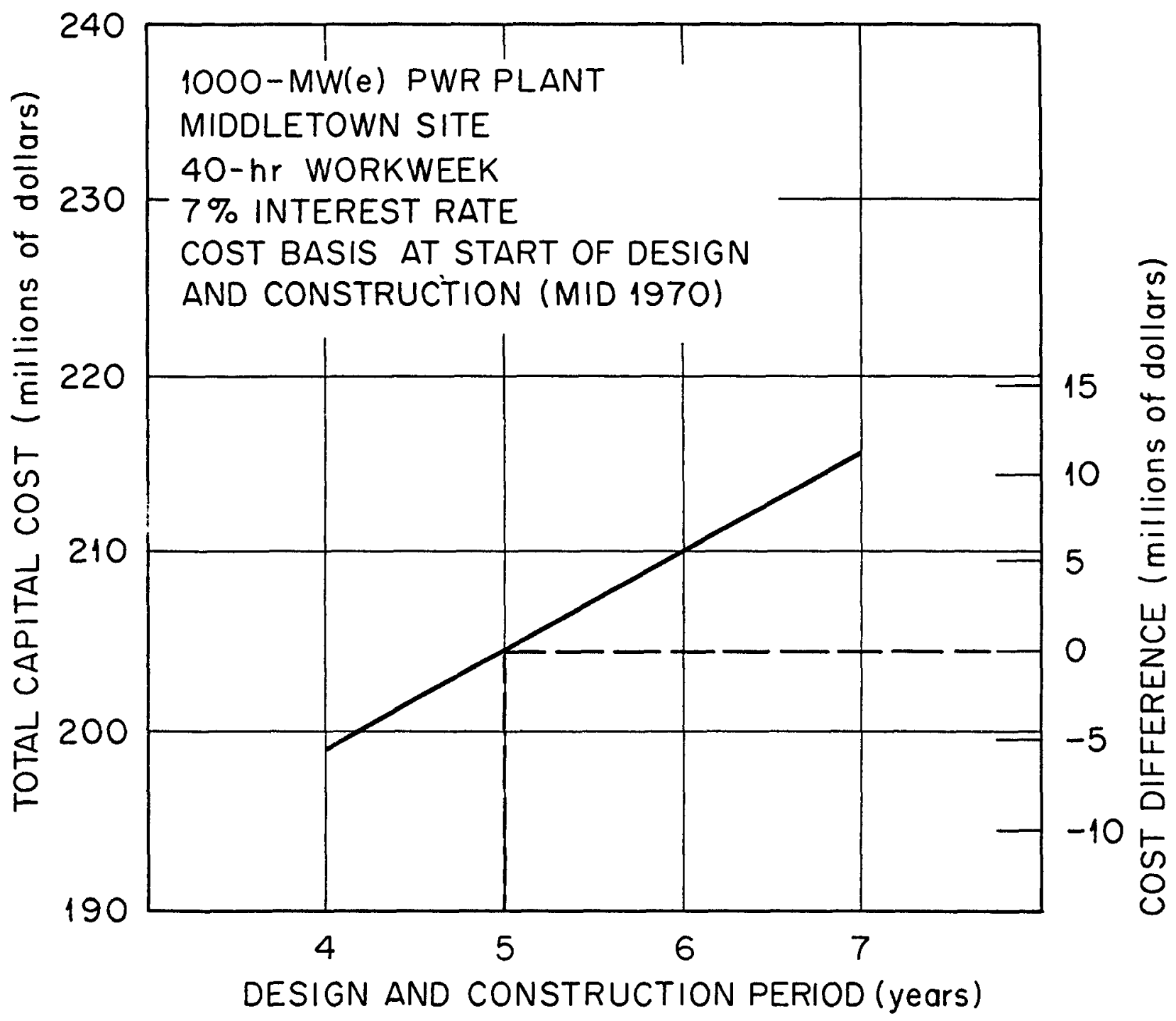

Fig. 19. Capital Cost as a Function of Design and Construction Period. 
ORNL-DWG 70-13324

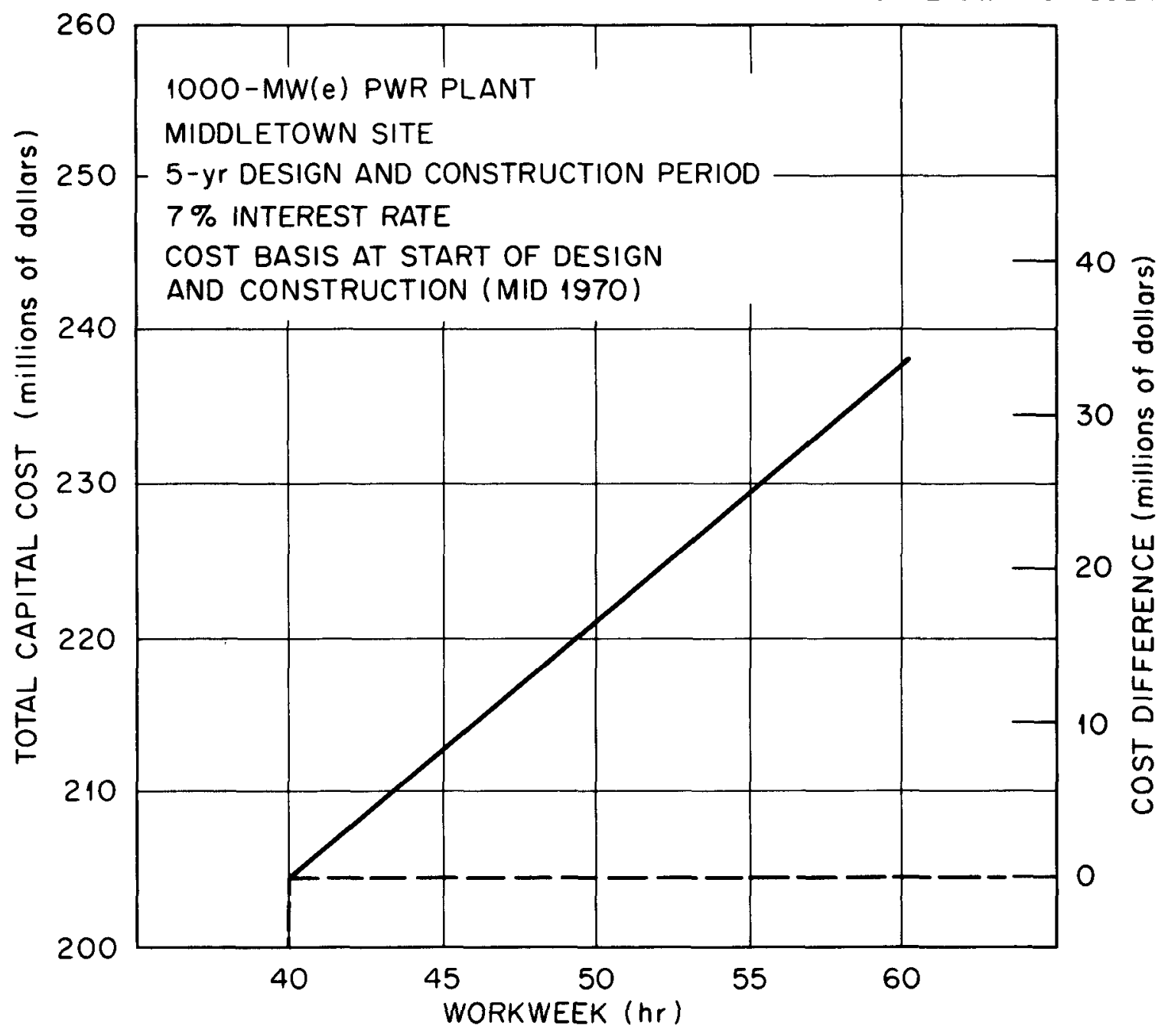

Fig. 20. Capital Cost as a Function of Workweek. 


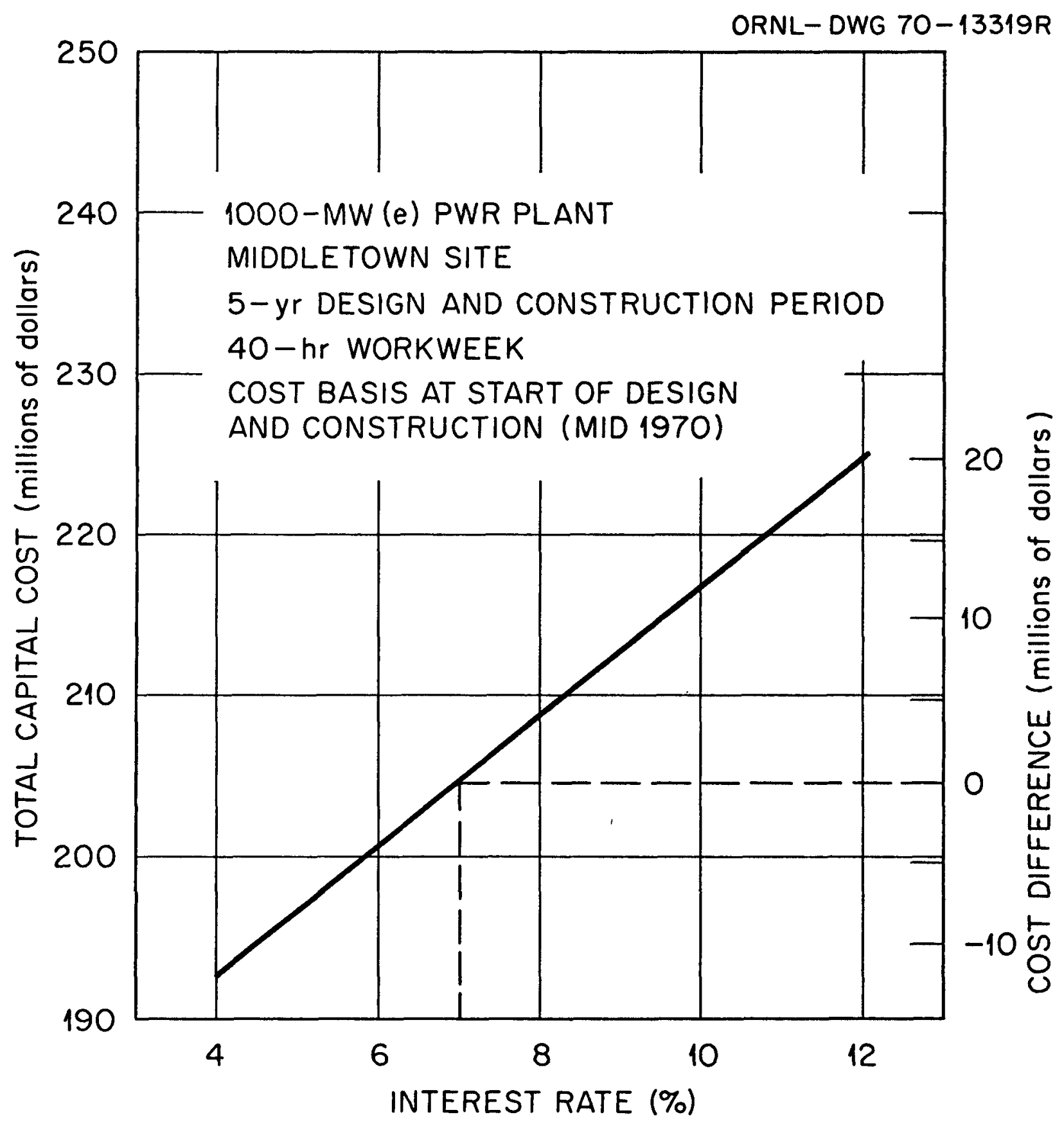

Fig. 21. Capital Cost as a Function of Interest Rate. 
The cumulative effect of (1) increasing the construction schedule from five to six years, (2) increasing the workweek from 40 to $45 \mathrm{hr}$, (3) increasing the interest rate from 7 to $8 \%$, and (4) including escalation during construction at $6 \%$ per year for six years can be estimated from the previous examples to increase the capital cost of the hypothetical $1000-\mathrm{MW}(\mathrm{e})$ plant by about $\$ 66$ million, as illustrated below:

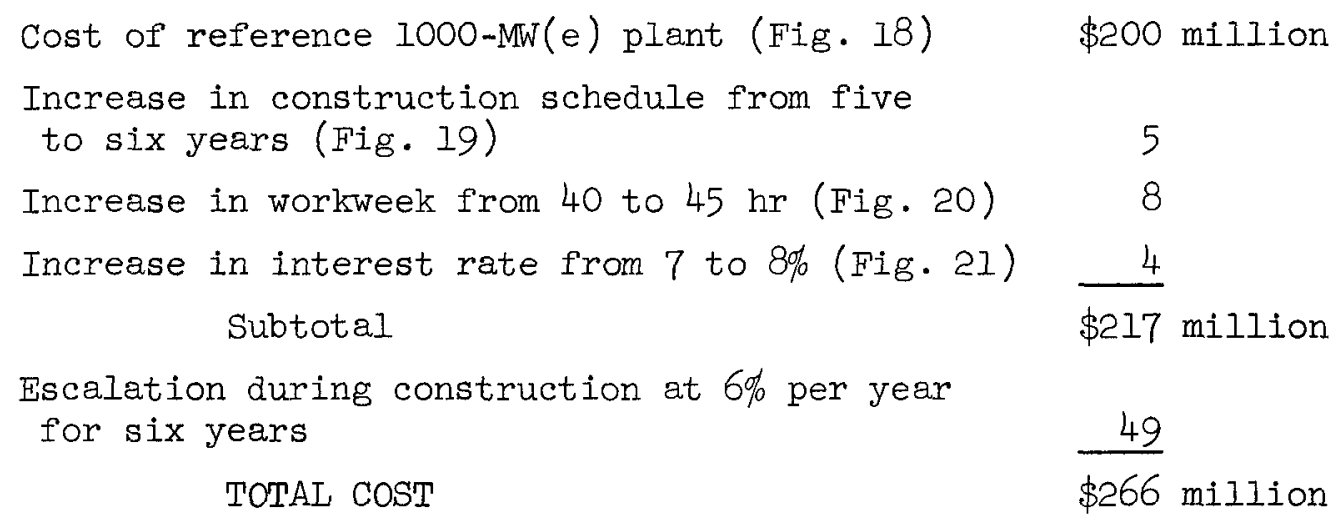

FUTURE WORK

This report is a summary of the current status of the capital cost computer program CONCEPT. Work is planned and continuing in the following areas :

1. A user's manual for CONCEPT (Phase 1) is being prepared.$^{5}$

2. The cost models are being improved and updated. This is a continuing task necessary to reflect changing technology, safety philosophy, and licensing and regulation requirements. United Engineers \& Constructors, under contract with AEC, is furnishing detailed cost estimates for a PWR plant provided with a run-of-river condenser circulating water system and with alternate cooling tower systems, which will be used to replace the current cost model. At Oak Ridge National Laboratory, cost model modifications are under development in the areas of transportation of major equipment and alternate heat-rejection systems.

3. Cost models are being developed that will allow more direct estimation of costs at the three-, four-, and five-digit levels.

4. Cost models will be developed for other types of power plants. United Engineers \& Constructors is also furnishing detailed cost estimates 
that will provide the basis for BWR, LMFBR, and fossil-fueled plant models. It is expected that cost models will also be developed for HTGR plants.

5. The cost indexes and projection techniques will be improved and updated to provide better projections of costs into the future. A method is being studied whereby projections can be weighted by regional and national trends as estimates are extended into the future.

6. A "building block" breakdown of capital costs will be developed that will allow a more logical grouping of costs than provided by the code of accounts. An example of the "building block" approach suggested by United Engineers \& Constructors follows: ${ }^{6}$

Nuclear steam supply system

Turbine-generator unit

Construction materials and equipment

Construction craft labor

\section{SUMMARY AND CONCLUSIONS}

A summary description of the current status of the computer program CONCEPT which is being developed to provide conceptual capital cost estimates for single-unit nuclear and fossil-fueled steam-electric power plants has been presented in this report. The one aspect of selecting alternate plants that contributes more to power generation costs than any other single factor is capital cost. CONCEPT has been designed to examine just this one factor in the long range examination of alternatives such as the AEC cost-benefit comparisons of various alternatives.7,8 CONCEPT is intended primarily as a tool for use in examining average trends in costs, evaluating important elements within the cost structure, and providing reasonable long range projections of costs. CONCEPT is not intended to provide substitutes for detailed cost estimates for particular plants at the time a utility company is faced with the decision of selecting among several vendors or plant sites. It is well appreciated that the competitiveness of the situation may well influence the cost of the plant and that the choice of a site may be one of probable acceptance by regulatory authorities and the public. 
Several examples of parametric calculations have been presented which illustrate the use of the code and their effects on capital costs of PWR plants. These examples illustrate that differences in costs of technical design features of nuclear power plants can be overwhelmed by economic parameters such as design and construction period, length of workweek required to attract site labor, interest rates, and escalation rates over which the designer has very little control.

This report has been reviewed by several industry groups, and many constructive suggestions have been included in both the Phase I effort and work planned for the future.

It is concluded that the code provides an improved means for making reasonable long range projections of capital costs for study purposes and that a continuing effort is required for improving and updating cost models to include other types of plants and to reflect changes in technology, safety philosophy, licensing and regulation requirements, and the economic climate. 


\section{REFERENCES}

1. NUS Corporation, Guide for Economic Evaluation of Nuclear Reactor Plant Designs, USAEC Report NUS-531, January 1969.

2. Engineering News-Record, McGraw-Hill, New York, published weekly.

3. Monthly Labor Review, U.S. Department of Labor, Bureau of Labor Statistics, published monthly.

4. Sees 70\% Rise in Plant Costs, Electrical World, p. 41, Jan. 15, 1971.

5. R. C. DeLozier, L. D. Reynolds, and H. I. Bowers, ConCEPT (Phase I User's Manual): Computerized Nominal Cost Estimates for SteamElectric Power Plants, USAEC Report ORNL-TM-3276, Oak Ridge National Laboratory (to be published).

6. U.S. Atomic Energy Commission, Trends in the Cost of Light Water Reactor Power Plants for Utilities, USAEC Report WASH-1150, May 1970.

7. U.S. Atomic Energy Commission, Cost-Benefit Analysis of the U.S. Breeder Reactor Program, USAEC Report WASH-1126, Apr11 1969.

8. U.S. Atomic Energy Commission, Potential Nuclear Power Growth Patterns, USAEC Report WASH-1098, December 1970. 